\title{
Capital Inflows, Credit Growth, and Financial Systems
}




\title{
WP/15/193
}

\section{IMF Working Paper}

\section{Capital Inflows, Credit Growth, and Financial Systems}

\author{
by Deniz Igan and Zhibo Tan
}

IMF Working Papers describe research in progress by the author(s) and are published to elicit comments and to encourage debate. The views expressed in IMF Working Papers are those of the author(s) and do not necessarily represent the views of the IMF, its Executive Board, or IMF management.
I N
N T E R N A T I O N A L
$M O N E T A R Y$
F U N D 


\title{
IMF Working Paper
}

Research Department

\section{Capital Inflows, Credit Growth, and Financial Systems \\ Prepared by Deniz Igan and Zhibo Tan ${ }^{\dagger}$ \\ Authorized for distribution by Giovanni Dell'Ariccia}

August 2015

IMF Working Papers describe research in progress by the author(s) and are published to elicit comments and to encourage debate. The views expressed in IMF Working Papers are those of the author(s) and do not necessarily represent the views of the IMF, its Executive Board, or IMF management.

\begin{abstract}
Exploiting a granular panel dataset that breaks down capital inflows into FDI, portfolio and other categories, and distinguishes between credit to the household sector and to the corporate sector, we investigate the association between capital inflows and credit growth. We find that non-FDI capital inflows boost credit growth and increase the likelihood of credit booms in both household and corporate sectors. For household credit growth, the composition of capital inflows appears to be more important than financial system characteristics. In contrast, for corporate credit growth, both the composition and the financial system matter. Regardless of sectors and financial systems, net other inflows are always linked to rapid credit growth. Firm-level data corroborate these findings and hint at a causal link: net other inflows are related to more rapid credit growth for firms that rely more heavily on external financing. Further explorations on how capital flows translate into more credit indicate that both demand and supply side factors play a role.
\end{abstract}

JEL Classification Numbers: E51, E44, F32

Keywords: Financial development, Financial structure, Capital flows, Credit

Authors’ E-Mail Address: digan@imf.org; tzb0905@fudan.edu.cn

\footnotetext{
${ }^{\dagger}$ Major part of the analysis presented in this paper was completed during Zhibo Tan's summer internship at the Western Hemisphere Department of the IMF. We are grateful to comments by Andre Meier, Martin Saldias, Ruud Vermeulen, and seminar participants at the IMF.
} 


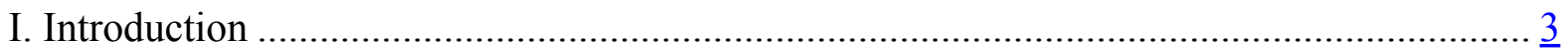

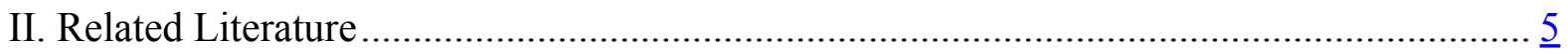

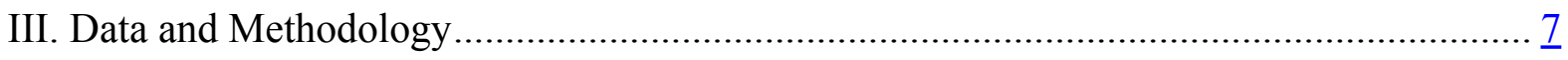

A. Data and Methodology in the Country-Level Analysis ....................................... 7

B. Data and Methodology in the Firm-Level Analysis ....................................... 10

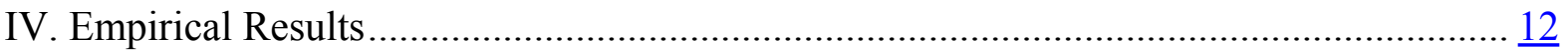

A. Capital Inflows and Credit Growth: Country-Level Evidence .............................. 12

B. Capital Inflows and Credit Growth: Firm-Level Evidence................................... 15

C. Discussion: Demand Boosts or Supply Expansions? .......................................... 16

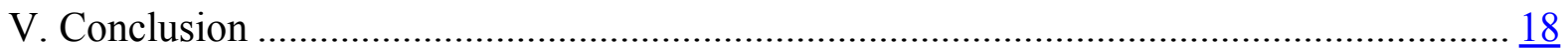

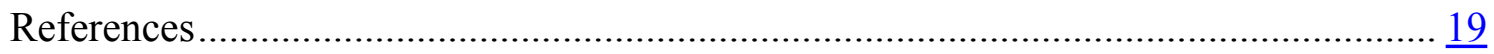




\section{INTRODUCTION}

Credit growth, and periods when it is abnormally rapid ("credit booms"), have come to the fore of academic and policy debate in the aftermath of the global financial crisis of 2007-08 and pose a dilemma. On the one hand, credit growth is often associated with financial deepening and beneficial to long-term economic growth (see Levine, 1997, for a review). On the other hand, it is also closely related to boom-bust cycles and financial crises (see, among others, Schularick and Taylor, 2012). A deeper understanding of the drivers of credit growth is essential to tell bad booms (booms ending up in a crisis) apart from good booms (booms that benefit long-term economic growth) and would better guide policies aiming to tame unsustainable credit growth.

Capital inflows are often considered to be a driver of credit growth and a trigger for credit booms (e.g., Hernandez and Landerretche, 1999; Sa, 2006; Elekdag and Wu, 2011; Calderon and Kubota, 2012; Mendoza and Terrones, 2012; Lane and Mcquade, 2013). However, to the best of our knowledge, the existing empirical studies have not yet exploited the more granular data that could help us understand better which way the causality actually runs.

In this paper, we compile a granular panel dataset for 33 countries covering the period 19802011 and present exploratory evidence on the complex relationship between capital inflows and credit growth. We not only break down capital inflows into different categories to find out whether the composition of capital inflows matters, but also examine credit growth by sectors (namely, the households and non-financial corporations) to detect whether there is any heterogeneity in the role of capital inflows for credit provided to different sectors. Moreover, we provide additional, suggestive evidence on the channels through which capital inflows would relate to credit growth. In particular, since domestic financial system is the main provider of credit, we inspect whether and how the development level and structure of the financial system enhances the linkages between capital inflows and credit growth.

In addition to the empirical analysis at the country level, we also provide complementary evidence on the linkages between capital inflows and credit growth at the firm level. Previous studies have analyzed these linkages only at the country level, where the direction of causality is very difficult to identify. It is possible that a domestic (supply or demand) shock generates rapid growth in credit provided by the domestic financial system, which, in turn or simultaneously, fuels sentiment, boosts asset prices, and pulls in international capital. In addition, there may be omitted factors correlated with both credit growth and capital inflows, leading to biased estimators and generating spurious associations. In comparison, our analysis at the firm level can better cope with these challenges. To begin with, countylevel capital inflows are beyond the control of individual firms. Therefore, they can be treated as exogenous to firm-level shocks and financing decisions and the direction of impact is relatively clearer. Furthermore, we can control for firm-level fixed effects in the analysis, which allows a more careful treatment of heterogeneities among firms, industries, and countries. Additionally, in a specification similar to Rajan and Zingales (1998), we interact an industry's dependence on external finance with different components of capital inflows. Hence, we take advantage of the differences at the industry level (the degree to which firms need credit) and country level (the degree to which an economy gets various types of capital 
inflows) simultaneously. This difference-in-difference estimation approach is better suited to pin down the causal link between capital inflows and credit.

Results suggest that capital inflows boost credit growth and increase the likelihood of credit booms in both household and corporate sectors. Furthermore, composition of capital inflows matters. Only non-FDI inflows are significantly associated with higher credit growth rates and credit booms for both the household sector and the corporate sector. Reassuringly, the firm-level evidence is consistent with the country-level evidence, demonstrating the robustness of our empirical results. Net other inflows, but not net FDI inflows, are related to more rapid credit growth for firms that rely more heavily on external financing.

For the linkages of capital inflows and household credit growth, the composition of capital inflows appears to be more important than financial system characteristics. ${ }^{1}$ Specifically, net other inflows are associated with faster growth in both shallow and deep markets. For the linkages of capital inflows and corporate credit growth, system characteristics matter more: capital inflows have a positive association with faster growth in more shallow and more bank-based systems. Regardless of financial systems, net other inflows are always linked to rapid credit growth. Further explorations on how capital inflows translate into credit growth indicate that both demand and supply side factors play a role.

We contribute to the literature in several aspects. First, we provide a more granular analysis of capital inflows and credit growth. We not only break down capital inflows into FDI, portfolio, and other flows, but also distinguish between credit to the household sector and to the corporate sector. Second, the firm-level analysis, which addresses the challenge of establishing causal links more prudently than country-level analyses do, corroborates the findings from country-level analysis and provides additional insights. Third, the evidence about the role of financial market characteristics for the associations between capital inflows and credit growth shed more light on these linkages.

We leave the extension of this analysis to "good versus bad" booms, but the evidence gathered here already has some policy implications. In particular, by documenting the links to credit developments for different types of capital inflows and across different financial systems, the analysis hints that a one-size-fits-all approach is not the right one and policymakers should take these details into account when they are deciding whether to respond to a surge in capital inflows because of credit market implications.

The rest of the paper is organized as follows. In Section II, we review the related literature. Section III introduces the data and methodology. The empirical results and discussions of the results are in Section IV. Section V concludes.

\footnotetext{
${ }^{1}$ We are interested in two main characteristics. First, financial depth or development, defined as the sum of stock market capitalization and private credit, in percent of GDP. Second, whether the system is bank or market based, or financial structure, defined as the log ratio of stock market capitalization to private credit.
} 


\section{RELATED Literature}

A great number of papers discuss the macroeconomic effects of credit booms (see, for instance, Mendoza and Terrones, 2012, and the references therein). There also exists extensive evidence that financial crises are often preceded by domestic credit booms (see, among others, Schularick and Taylor, 2012). Nevertheless, these studies do not focus on the drivers of credit growth. A few studies (for example, Djankov et al., 2007) scrutinize the determinants of cross-country variation in credit-to-GDP ratios, emphasize creditor protection through the legal system and information sharing institutions rather than the role of financial openness and capital flow surges. Furthermore, this line of the literature focuses on differences in the development stages (developing and advanced countries), rather than on the distinctions of financial system features.

When it comes to the triggers of credit growth, Elekdag and $\mathrm{Wu}$ (2011) discuss the external and domestic factors that are associated with credit booms based on event studies of 99 credit booms. Bruno and Shin (2013) examine the impacts of global liquidity and leverage cycles on international banking inflows and credit growth. Neither study directly explores the linkage between capital inflows and credit booms.

Our paper is closely related to a range of papers that specifically discuss the role of capital inflows. Hernandez and Landerretche (1999) provide supporting evidence that surges in capital inflows tend to finance a credit boom. Sa (2006) examines the role of capital inflows in credit expansion in 27 emerging countries during 2002-06 and fails to find a clear-cut causal relationship between capital inflows and credit booms. Mendoza and Terrones (2012) find that credit booms often follow surges in capital inflows. Calderon and Kubota (2012) report that surges in gross debt inflows are a good predictor of subsequent credit booms in a sample of 71 countries from 1975q1 to 2010q4. Lane and Mcquade (2013) point out that domestic credit growth in European countries is strongly related to net debt inflows but not to net equity inflows.

Our paper complements the analyses in these papers in several aspects. First, differing from Hernandez and Landerretche (1999), Sa (2006), and Mendoza and Terrones (2012), we break down capital inflows into FDI, portfolio, and other categories, so as to detect whether the composition of capital inflows matters. Second, these papers do not categorize credit by the end user. Employing a recent dataset compiled by Bank for International Settlements (BIS), we are able to carry out a more granular analysis of private credit to households and private credit to non-financial corporations and investigate the heterogeneity across sectors. Third, these studies do not explore the role of the financial system, an important dimension to comprehend the diverse impact of different kinds of capital inflows. ${ }^{2}$

\footnotetext{
${ }^{2}$ Magud et al. (2012) inspect credit booms during periods of large capital inflows, but their focus is on the exchange rate regime. They are also more interested in the level of credit to GDP, rather than its growth rate. We instead focus on the growth of credit and examine the role of financial system characteristics, controlling for exchange rate regime.
} 
Furthermore, all the existing analyses are at the country level and, hence, subject to endogeneity and the direction of causality is difficult to identify. ${ }^{3}$ In comparison, we not only provide empirical evidence at the country level, but also supplement it with supporting evidence at the firm level. Since capital inflows are beyond the control of individual firms, the direction of causality is, arguably, clearer. Also, the interaction term of capital inflows and an industry's dependence on external financing, which in essence is a difference-indifference estimator, is able to capture the effects of capital inflows better. In addition, the control of fixed effects at the firm level can attenuate the omitted variable bias to a greater extent than the control of country-level fixed effects.

Last but not least, with respect to the methodology to identify the boom periods, existing studies either make use of the standard HP filter, ${ }^{4}$ which requires information about the whole history, or the expanded HP filter with an ad hoc boom threshold that is invariant across countries, ${ }^{5}$ regardless of the historical variability of credit in a specific country. We identify the boom periods with only information available at a specific time point and combine a country-specific, trend-based approach with ad hoc thresholds, which is more realistic and relevant for policy makers. ${ }^{6}$

Concerning micro-level evidence, our approach is similar to that in Abiad et al. (2012) and in Tong and Wei (2012), but these studies focus on the other side of the coin. Abiad et al. (2012) zoom in on the aftermath of credit booms and show that sectors more dependent on external finance suffer more during creditless recoveries. Tong and Wei (2012) deliver evidence that pre-crisis exposure to non-FDI capital inflows worsens the credit crunch of firms that are intrinsically more dependent on external finance for working capital.

In a related strain of research, there is ample empirical evidence on the links between capital inflows (or its mirror image, current account deficits) and asset prices, which shed light on the demand side channels through which capital inflows might trigger credit booms. For instance, Aizenman and Jinjarak (2009) find robust and strong positive associations between current account deficits and the appreciation of real estate prices. Sa and Wieladek (2010) suggest that capital inflows, compared with monetary policy loosening, played a bigger role in the U.S. housing boom that culminated in the global financial crisis. Based on a dataset covering 45 countries from 1990 to 2012, Vasquez-Ruiz (2012) finds that capital flows affect house prices positively and significantly. Reversely, Laibson and Mollerstrom (2010) demonstrate that, movements in home prices alone explain half of the variation in trade deficits in a sample of 18 OECD countries plus China. Jansen (2003) and Kim and Yang (2011) show that capital inflows contribute to asset price appreciation in Thailand and other emerging Asian economies. Olaberria (2011), using panel data on 40 countries from 1990 to 2010, points out that the linkages between capital inflows and asset price booms varies across

\footnotetext{
${ }^{3}$ An earlier version of Mendoza and Terrones (2012) — the working paper dated 2008 —includes some descriptive analysis, but no regressions, at the firm level.

${ }^{4}$ See Mendoza and Terrones (2012) for details.

${ }^{5}$ The methodology is first proposed by Gourinchas, Valdes, and Landerretche (2001).

${ }^{6}$ Section III provides a detailed discussion of the methodology.
} 
capital inflow categories and across countries, and such connections are more evident in emerging economies. Sa, Towbin, and Wieladek (2014) estimate a VAR model on a panel of 18 OECD countries and find that capital-inflow shocks have a significant and positive effect on real house prices, real credit available to the private sector, and real residential investment - with stronger effects in countries with more developed mortgage markets and in countries where securitization is allowed.

There is also abundant research offering insights on the transmission channels from the supply side. For example, Dell'Ariccia and Marquez (2006) show that, as banks obtain private information about borrowers and information asymmetries across banks decreasewhich often follow financial liberalization and capital inflows-banks may loosen their lending standards, leading to an equilibrium with expanded aggregate credit. Dell'Ariccia, Igan, and Laeven (2012) find that deterioration of lending standards are associated with larger credit booms and house price increases and entry of new, large lenders trigger declines in lending standards by incumbent banks.

While we do not directly investigate asset prices or lending standards, these papers endow us with potential perspectives to comprehend how capital inflows trigger rapid credit growth episodes. On the demand side, stock price and house price appreciation increases household wealth, which in turn promotes consumption and boosts demand for credit. Asset price increases also enhance collateral value of firms, improve their balance sheet, and help them get access to more credit. On the supply side, banks tend to issue more credit as capital inflows create liquidity and there are more resources at their disposal. In addition, the entry of foreign capital may intensify competition and pose a threat to domestic banks. They may react to this threat by issuing more credit.

\section{Data And Methodology}

Our empirical analysis is carried out in two steps. First, we utilize country-level data to investigate the association of different types of capital inflows with credit growth at the macro level. Second, we use a firm-level dataset to explore the impact of capital inflows on credit growth.

\section{A. Data and Methodology in the Country-Level Analysis}

We compile a panel dataset of 33 countries covering the period 1980-2011. ${ }^{7}$ Data are obtained from the Bank for International Settlements (BIS) credit to private sector database, the IMF's World Economic Outlook (WEO) database, the World Bank's database on Financial Development and Financial Structure, ${ }^{8}$ Reinhart and Rogoff (2004), and Chinn and Ito (2008). We provide more detailed information when we discuss specific variables.

\footnotetext{
${ }^{7}$ The list of countries is: Australia, Austria, Belgium, Canada, China, Czech Republic, Denmark, Finland, France, Germany, Greece, Hong Kong SAR, Hungary, India, Indonesia, Ireland, Italy, Japan, Korea, Mexico, Netherlands, Norway, Poland, Portugal, Singapore, South Africa, Spain, Sweden, Switzerland, Thailand, Turkey, United Kingdom, and United States.

${ }^{8}$ Beck et al. (2000) describe the database, which is updated periodically, in detail.
} 
To study how a country's credit growth is linked with capital inflows, our baseline specification is as follows:

$$
y_{i t}=\alpha N C I_{i t-1}+\beta X_{i t-1}+v_{i}+\eta_{t}+\varepsilon_{i t}
$$

where the subscripts $i$ and $t$ are indices for countries and years, respectively; $y$ is growth rate of the credit-to-GDP ratio; NCI stands for net-capital-inflows-to-GDP ratio; $X$ is a set of control variables; $v$ and $\eta$ are, respectively, country and year fixed effects; $\alpha$ and $\beta$ are parameters to be estimated; and $\varepsilon$ is the error term. All explanatory variables are lagged by one period to mitigate reverse causality concerns (higher credit growth attracts more capital inflows).

The credit series is obtained from the database of credit to the private sector compiled by BIS. The series are adjusted for breaks and breaks down private credit into credit to nonfinancial corporations and credit to households. ${ }^{9}$ This allows us to study the diverse impacts of capital inflows on credit growth for different sectors. Since credit is a stock variable measured at year end while GDP is a flow variable, the credit to GDP ratio is constructed with the geometric average of GDP in years $t$ and $t+1$, following Dell'Ariccia et al. (2012).

The variable of interest is net capital inflows. To provide a granular analysis of capital inflows, we further categorize net capital inflows into net FDI inflows, net portfolio inflows, and net other inflows. Data are from the WEO Database.

Similar to Magud et al. (2012), in $X$ we include the usual suspects that are related to credit growth: log real GDP per capita and its square term, real GDP growth rate, broad-money-toGDP ratio, inflation, deposit interest rate, ${ }^{10}$ change of nominal exchange rate, ${ }^{11}$ exchange rate regime, import-and-export-to-GDP ratio, and capital control index. The first three variables account for the effects of development stage and growth momentum on credit growth. As the descriptive evidence in Dell'Ariccia et al. (2012) shows, middle-income countries and highgrowth countries are more likely to experience rapid credit growth. Broad-money-to-GDP ratio controls for disposable funding for credit in the financial system. The inclusion of inflation, interest rate, and change of exchange rate (national currency per U.S. dollar) separate the impact of price and price adjustments on credit growth. The data source of all these variables is the WEO database. The measure for exchange rate regime is from Reinhart and Rogoff (2004)'s coarse classification and the subsequent update by Ilzetski, Reinhart, and Rogoff (2010), with higher values indicating a more flexible exchange rate regime. Updates for 2008-11 are based on changes in exchange rate regimes as described in the IMF's Annual Report on Exchange Arrangements and Exchange Restrictions (AREAER). Import-and-export-to-GDP ratio (openness) and capital control index are to account for a

\footnotetext{
${ }^{9}$ Dembiermont et al. (2013) give a detailed description of the database.

${ }^{10}$ Controlling for lending interest rate instead of deposit interest rate delivers similar results although the sample size is reduced due to data availability.

${ }^{11}$ Controlling for change of real effective exchange rate instead of change of nominal exchange rate yields similar results although the sample size is reduced due to data availability.
} 
country's policies toward opening its economy. Data on openness is from the WEO database. Capital control index is from an updated version of Chinn and Ito's financial openness index (Chinn and Ito, 2008), which measures a country's degree of capital account openness based on binary variables that codify the tabulation of restrictions on cross-border financial transactions reported in the IMF's AREAER. Higher value of the index indicates higher degree of openness. Panel A of Table 1 presents summary statistics for all these macroeconomic variables.

As complementary evidence, we investigate whether capital inflows are associated with credit booms (that is, periods of abnormal credit growth) as well. Following the methodology in Dell'Ariccia et al. (2012), we define an episode of rapid credit growth as a credit boom when the deviation from trend exceeds a country- and path-dependent threshold or the credit growth rate goes beyond an ad hoc criterion. To be specific, for a particular country in each year $t$, we estimate a rolling cubic trend between $t$ and $t-10$ for this country and compare the deviation of the credit-to-GDP ratio from this trend. The cubic trend lets us introduce two inflection points so that both financial deepening and its reversal are allowed. A data point becomes the peak of a boom if either of the following conditions is satisfied: (i) the deviation from trend is greater than 1.5 times its standard deviation and the annual growth rate of the credit-to-GDP ratio exceeds 10 percent; or (ii) the annual growth rate of the credit-to-GDP ratio exceeds 20 percent. To exclude the possibility that a positive change in the credit-toGDP ratio is actually owing to a GDP contraction, we eliminate the peaks identified by this algorithm when GDP growth is negative. Differing from the methodology in Mendoza and Terrones (2012), who utilize HP filter that employs the whole set of information available in the sample, this method permits us to make use of only the currently available information to judge credit growth developments, which is more relevant and realistic for policy makers. ${ }^{12}$

In order to define the boom episodes, we also need to identify the start and the end of a boom. Similar to Dell'Ariccia et al. (2012), the start of the boom is defined as the earliest year in which either (i) the credit-to-GDP ratio exceeds its trend by more than three-fourths of its historical standard deviation and its annual growth rate exceeds 5 percent; or (ii) its annual growth rate exceeds 10 percent. A boom ends as soon as either (i) the growth of the credit-to-GDP ratio turns negative; or (ii) the credit-to-GDP ratio falls within three-fourths of one standard deviation from its trend and its annual growth rate is lower than 20 percent.

After identifying boom episodes in the household sector and the corporate sector, we define a dummy for credit booms in both sectors respectively - which takes the value of 1 if sector in a given country is experiencing a boom in a specific year, and 0 otherwise. As complementary evidence, we replace the credit growth variable in Equation (1) with the dummy for credit booms and estimate a linear probability model with fixed effects. ${ }^{13}$

\footnotetext{
${ }^{12}$ For example, if the sample period is $1980-2011$, the trend is estimated using all the observations in 19802011, which is less useful to a policy maker making a decision, say, in 1990, because the information about 1991-2011 is not available to the policy maker yet.

${ }^{13}$ Results — not reported for sake of brevity — are broadly the same when a logit model is used.
} 
As robustness checks, we estimate alternative specifications by adding in the level term of all right-hand-side variables. We also utilize the one-period lag of capital inflows (or its components) as an instrument for the level of capital inflows (or its components) and run 2SLS regressions. The results are basically the same, so we only report the baseline results due to space limits.

Different from the existing studies, we also investigate whether and how the characteristics of the financial system (financial development and financial structure) relate to the linkages between capital inflows and credit growth. Financial development is measured as the sum of the private-credit-to-GDP ratio and the stock-market-capitalization-to-GDP ratio. Following Beck and Levine (2002), we define financial structure as a continuous variable measuring the relative size of market-based finance over bank-based finance. It is the log ratio of the stock market capitalization to bank loans issued to the private sector. Higher values of this variable are associated with a financial system that is more reliant on capital markets. Data about financial development and financial structure are obtained from the World Bank's database on Financial Development and Financial Structure. To explore the role of the financial system, we divide the whole sample into two subsamples according to the median value of financial development and financial structure, and carry out the same regression analysis in the two subsamples as before. This allows for a more general specification than adding in interaction terms.

\section{B. Data and Methodology in the Firm-Level Analysis}

Although we include many controls and lag explanatory variables, a drawback of the analysis at the country level is that the endogeneity issue is still a concern. There might be some omitted common factors that are correlated with capital inflows and credit growth simultaneously. Furthermore, it is difficult to distinguish whether credit growth is driven by demand- or supply-side factors, which might have different policy implications. Considering these challenges, we utilize firm-level data to verify that the basic patterns revealed at the country-level analysis about the associations of capital inflows with credit growth still hold. ${ }^{14}$ The analysis is justified by the fact that country-level capital inflows are beyond the control of individual firms and the control of firm-level fixed effects make endogeneity less of a concern. Moreover, analysis following Rajan and Zingales (1998) remedy the endogeneity issue further. Although we are not able to differentiate the demand side from the supply side completely, we can get some hints from firm-level evidence.

All the firm-level data are acquired from the financial statements of listed firms compiled by Thomson Reuter's Worldscope Database. To maintain consistency with the country-level analysis, we only include firms located in our 33-country sample. Due to data availability, the time span is 1991-2011. Our specification for the firm-level analysis is as follows:

$$
y_{i j k t}=\gamma R Z_{j t} \times N C I_{k t}+\alpha_{1} R Z_{j t}+\alpha_{2} N C I_{k t}+\beta_{1} F_{i j k t-1}+\beta_{2} M_{k t}+v_{i}+\eta_{t}+\varepsilon_{i j k t}
$$

\footnotetext{
${ }^{14}$ Due to data limitations, we can only provide firm-level micro evidence because household-level panel data are not widely available.
} 
where the subscripts $i, j, k$, and $t$ are indices for firms, industries, countries, and years, respectively; $y$ is the change in the ratio of total debt to sum of total debt and total equity (or the growth rate of total debt to total asset ratio, or the growth rate of total debt, depending on the specification; ${ }^{15} R Z$ is the Rajan-Zingales index measuring an industry's dependence on external financing; $N C I$ stands for net-capital-inflows-to-GDP ratio; $F$ and $M$ are a set of firm-level and country-level control variables; $v$ and $\eta$ are, respectively, firm and year fixed effects; $\alpha, \beta$, and $\gamma$ are parameters to be estimated; and $\varepsilon$ is the error term. The firm-level control variables are lagged one period to mitigate reverse causality concerns. The robust standard errors are clustered at the industry level, allowing for correlations among firms within the same industry.

We discuss variables in Equation (2) step by step. In terms of the dependent variable, we employ the total equity or total assets to scale the amount of total debt. To eliminate the possibility that leverage growth is due to the change in total equity or in total assets, we investigate the growth of total debt as well. In case of outliers, top and bottom 5 percent observations of all these variables are winsorized for each country.

$R Z$ index is constructed following Rajan and Zingales (1998). Specifically, we calculate the dependence on external finance for each U.S. firm in year $t$ and the $R Z$ index is the median value of this indicator for each industry (SIC 2-digit level). Differing from Rajan and Zingales (1998), we have a panel dataset and the same method is applied each year. Therefore, our $R Z$ index varies over industry and year. Dependence on external finance is computed as the ratio of (capital expenditures-cash flow) to capital expenditures and cash flow equals the sum of cash flow from operations, decrease in inventories, decrease in receivables, and increase in payables. As Rajan and Zingales (1998) argue, the United States has the most advanced financial markets and firms face the least external financing difficulties, and as a result the dependence of U.S. firms on external financing reflect the pure technological characteristics of a particular industry. In other words, the construction of this indicator based on U.S. firms is the least subject to the influence of other non-technological factors on the demand for external financing, such as financial market restrictions and institutional deficiencies.

The interaction term of $R Z$ index and capital inflows is of particular interest. A positive $\gamma$ indicates that a firm depending more on external finance experiences more credit growth in response to capital inflows. If this is the case, it is clearer that capital inflows lead to credit growth since the estimator for $\gamma$ is essentially a difference-in-difference estimator that allows us to take advantage of industry- and country-level variations simultaneously, and control for industry- and country-level fixed effects, which might obscure the impact of capital inflows.

Following Rajan and Zingales (1995), in $F$ we include a series of usual determinants of a firm's credit access, such as the ratio of property, plant and equipment to total assets, Tobin's

\footnotetext{
${ }^{15}$ Note that the firm-level measure of credit relies on a broader definition of credit that includes portfolio debt, compared to the country-level measure of credit.
} 
$q$, earnings before interest and tax (EBIT) to total assets, and the log of sales. The first variable measures the tangibility of assets, which determines the value of collateral and degree of information asymmetry. On the one hand, firms with more tangible assets have more collateral to pledge, which is helpful to raise debt. On the other hand, these firms are less subject to information asymmetry and are more likely to issue equity. Gauging the firms' growth opportunities, Tobin's $q$ is calculated as the sum of market capitalization and total debt to total assets. According to Myers (1977), highly leveraged firms are more likely to pass up profitable opportunities, so firms expecting higher growth should use less debt finance. If this argument holds, we should observe a negative coefficient for Tobin's $q$. The ratio of EBIT to total assets captures the profitability of a firm. More profitable firms are more capable of acquiring debt but they may also rely more heavily on their own internal financing, which is less costly. The size of a firm, measured by the log of sales, affects the capacity to issue debt and equity simultaneously. Larger firms get easier access to both debt and equity. Therefore, the impact on credit growth in this case is ambiguous as well.

As robustness checks, we also employ receivables and inventory to total assets to measure tangibility, the ratio of (market capitalization + asset - equity) to total assets to measure Tobin's $q$, and the log of total assets to control for firm size. In further checks, we add interest expense to net income, $Z$-score, ${ }^{16}$ the ratio of cash and short-term investment to total assets, the ratio of the sum of net income and depreciation to total assets stepwise to control for the influence of interest payment pressure and tax shield, bankruptcy probability, asset liquidity and cash flows. Moreover, top and bottom 1 percent observations of all firm-level control variables are winsorized for each country to ensure that the results are not driven by the outliers. The summary statistics of all firm-level variables are presented in Panel B of Table 1.

In $M$, we include all the macroeconomic variables in the country-level regressions to keep the analysis in a coherent framework.

\section{EMPIRICAL RESULTS}

In this section, we first present the results of the country-level analysis and then examine the firm-level evidence.

\section{A. Capital Inflows and Credit Growth: Country-Level Evidence}

Table 2 presents the baseline country-level results. Columns (1)-(4) are based on credit to the household sector. In columns (5)-(8), estimation results for credit to the corporate sector are shown. Overall, the results demonstrate that capital inflows are significantly associated with credit growth of both the household sector and the corporate sector. Greater capital inflows boost the credit growth rate and increase the probability of a boom. Further inquiry reveals

\footnotetext{
${ }^{16} \mathrm{Z}$-score $=0.717 * \mathrm{Z} 1+0.847 * \mathrm{Z} 2+3.107 * \mathrm{Z} 3+0.420 * \mathrm{Z} 4+0.998 * \mathrm{Z} 5 . \mathrm{Z1}$ is working capital to total assets. $\mathrm{Z2}$ is retained earnings to total assets. Z3 is EBIT to total assets. $Z 4$ is market value of equity to book value of total liabilities. Z5 is sales to total assets.
} 
that the composition of capital inflows matters. For household credit, only net portfolio inflows and net other inflows play a significant role while net FDI inflows are not significant. For corporate credit growth, only net other inflows are significant. Although net FDI and portfolio inflows are significant in explaining the probability of a corporate sector credit boom, FDI is only marginally significant. In all the cases considered, only net other inflows are always significant.

The distinction between FDI inflows and non-FDI inflows can account for such difference. FDI inflows are long-term oriented and are usually related with activities in the real economy, such as the expansion of production capacity. They are more stable than portfolio inflows or other inflows, which are more myopic and often aim at short-term speculative opportunities. Non-FDI inflows are more likely to be associated with an appreciation in real asset prices (Olaberria, 2011) and, through collateral values and exuberance, may propel credit expansion.

What about the economic magnitude of the effect? Based on columns (1) and (5), ceteris paribus, the increase of net-capital-inflows-to-GDP ratio by one standard deviation is associated with the rise of household and corporate credit growth rate by 0.07 and 0.21 standard deviations, respectively. Similar calculations based on columns (2) and (6) reveal that the corresponding figures for net other inflows are 0.09 and 0.07.

In terms of other significant coefficients in the regression analysis, higher real GDP growth rate is associated with more rapid household credit growth and higher probability of a household credit boom, consistent with Dell'Ariccia et al. (2012). In addition, similar to the finding in Magud et al. (2012), a more flexible exchange rate regime reduces the growth rate of corporate sector credit. In economies with a more flexible exchange rate regime, exchange rate will adjust automatically and alleviate the pressure of credit growth.

Although we include the usual suspects that drive credit growth, there might still be omitted variable bias and measurement error. To alleviate these problems, we implement IV regressions, utilizing the one-period lag of capital inflows (and its components) as instruments for the level term of capital inflows (and its components). The basic patterns still hold. $^{17}$

The domestic financial system is often the primary provider of credit and also acts as an intermediary in processing capital inflows. Therefore, financial system characteristics have a bearing on the relationship between capital inflows and credit growth. In the following, we focus on two aspects of the financial system: the absolute degree of development of the banking sector and the stock market (financial development), and the relative degree of development of the stock market versus the banking sector (financial structure). To allow for a more general specification, we divide our sample into two subsamples using the median value of financial development and financial structure in the whole sample as a cut-off. Given that information on stock market capitalization did not become widely available until

\footnotetext{
${ }^{17}$ These results are not reported for sake of brevity and are available from the authors upon request.
} 
1989, the sample period is narrowed down to 1989-2011 in this exercise. The results for the household sector and the corporate sector are presented in Table 3 and Table 4, respectively.

Column (1) of Table 3 shows that, despite the loss of about a decade in the sample period, net other inflows are still positively linked with credit growth for the household sector. Other types of capital inflows do not seem to matter. Further breakdown by financial development in columns (2) and (3) demonstrates that net other inflows are significant in both subsamples, while net portfolio inflows become significant in the high financial development group. In unreported regressions, we divide the sample only by the bank-credit-to-GDP ratio and then only by the stock-market-capitalization-to-GDP ratio (rather than by their sum) and observe that banking sector development is what is driving this finding, rather than stock market development. In economic terms, if net-other-inflows-to-GDP ratio increases by one standard deviation, the growth rate of household credit rises by 0.35 and 0.08 standard deviations in the high banking development group and the low banking development group, respectively.

How to explain this finding? The answer may lie in the fact that the main provider of credit to households is banks (households cannot raise funds in the stock market directly). Therefore, the development of the banking sector matters more for household credit growth. When the degree of development of the banking sector is very low, portfolio inflows may not be fully utilized and transformed into household credit. Only when the banking sector is advanced, net portfolio inflows begin to matter for household credit.

The financial structure, i.e., the relative degree of development of the stock market versus the banking sector, is another critical aspect of a financial system. Comparing the results in columns (4) and (5), it is clear that linkages of capital inflows and household credit growth are similar in these two groups. In other words, financial structure does not matter for the connections between capital inflows and household credit growth. This is in line with Tan et al. (2013), who provide empirical evidence that financial structure is irrelevant for household saving behavior but plays a big role in corporate financing and saving behavior.

Turning to credit to the corporate sector, column (1) of Table 4 shows that net other inflows continue to be significant in the reduced sample. Furthermore, columns (2)-(5) demonstrate that net other inflows are always significant regardless of financial system characteristics. By contrast, portfolio inflows are only significant in a less developed financial system. Both FDI inflows and portfolio inflows are significant in a more bank-based system, but not in a more market-based system. Separate analysis based on the banking and stock market components of the financial development metric reveals that it is the degree of development of the stock market that matters. An increase of net-other-inflows-to-GDP ratio by one standard deviation is associated with a rise in corporate credit growth rate by 0.25 standard deviations in the highly-developed stock markets and 0.39 standard deviations in less-developed stock markets. The corresponding figures in a more market-based system and less market-based system are 0.31 and 0.46 , respectively.

What accounts for these differences in how capital inflows relate to corporate credit growth? Different from households, firms are able to get equity financing in the stock market. If a country has a more advanced stock market, firms do not need to rely a great deal on bank 
loans. As a result, portfolio inflows are less likely to trigger rapid credit growth in such markets. Only in shallow stock markets where inflows cannot be as easily absorbed does the association of portfolio inflows and corporate credit growth become significant. An alternative way of putting this argument is that large portfolio inflows are more likely to push valuations in shallower markets, potentially spilling over to other types of financing through collateral and balance sheet effects. The same line of reasoning could also shed some light on why even FDI inflows turn out to be significant in a less market-based (or more bank-based) financial system.

\section{B. Capital Inflows and Credit Growth: Firm-Level Evidence}

The regression results based on Equation (2) are displayed in Table 5. In the first three columns, we employ the growth rate of [total debt / (total debt + equity)] as the dependent variable. In the last three columns, we replace the dependent variable with the growth rate of (total debt / total assets). These indicators are both utilized widely in the literature to characterize a firm's leverage. ${ }^{18} \mathrm{We}$ add the firm-level control variables stepwise. The coefficient on the interaction term of net other inflows and the $R Z$ index is robust to different sets of control variables. When we substitute the dependent variable in columns (4)-(6), the interaction term remains significant. These results show that firms which depend more on external financing experience faster credit growth in response to net other inflows. Since country-level capital inflows are beyond the control of individual firms and the interaction term is in essence a difference-in-difference estimator purging out country and firm fixed effects, this evidence not only corroborates the findings at the country level but also supports a causal link from net other inflows to corporate credit growth. ${ }^{19}$ The interaction term of net FDI inflows and the $R Z$ index is not significant while the interaction term of net portfolio inflows and the $R Z$ index is only significant in some specifications, confirming the basic patterns in the country-level analysis. The composition of capital inflows matters.

In terms of other significant control variables, the coefficient on tangibility of assets is negative. This suggests that firms with less information asymmetry find it easier to issue equity rather than use loan financing. Tobin's $q$ is significantly negative, consistent with fastgrowing firms missing up investment opportunities due to debt overhang problem and counting less on debt financing in anticipation of this (Myers, 1977). The coefficient on the $\log$ of sales is significantly negative, possibly suggesting that the debt growth rate for larger firms is smaller because they have easier access to the stock market and fewer expansion opportunities. In line with the predictions of classic models, less interest payment pressure, lower probability of bankruptcy, and higher liquidity ratio enhance the capacity to raise debt and they are associated with faster growth of the debt ratio.

\footnotetext{
${ }^{18}$ See Rajan and Zingales (1995) for a discussion of pros and cons of these indicators.

${ }^{19}$ Admittedly, this argument is weaker in the case of certain small open economies that host large multinationals that finance themselves in international money and capital markets (such as Netherlands and Sweden).
} 
With respect to country-level control variables, higher real GDP growth, lower inflation, lower money supply, higher interest rates, and greater capital account openness are all related to faster growth of the firm debt ratio.

We do a series of robustness checks. First, in Table 6, we substitute alternative measures for the key firm-level control variables. To be specific, we replace the ratio of property, plant and equipment to total assets with the ratio of receivables and inventory to total assets to characterize tangibility, use the ratio of (market capitalization + asset - equity) to total assets to measure Tobin's $q$, and employ the log of total assets to control for firm size. We then replicate the analysis in Table 5. The baseline results are robust to these alternative measures.

Next, we reconsider the effect of outliers. Although we have winsorized the firm-level variables in the baseline, the range of dependent variables and some control variables is still wide. In order to verify that the results are not driven by outliers, we further drop the top and bottom 5 percent observations of dependent variables, and top and bottom 1 percent observations of $Z$-score and the ratio of the sum of net income and depreciation to total assets in the winsorized sample. ${ }^{20}$ The results are presented in the first four columns of Table 7 , demonstrating that the baseline results are robust to alternative ways of defining outliers.

Finally, to make sure that the baseline results are not driven by growth in equity rather than growth in debt, we separate debt and equity and replace the dependent variable with the growth rate of debt and the growth rate of equity, respectively. The results are displayed in the last two columns of Table 7 and show that equity growth is not significantly affected by the interaction term of capital inflows and the $R Z$ index. In other words, the baseline results reflect the impact of capital inflows on debt growth and are not contaminated by equity growth.

In sum, firm-level evidence corroborates the basic patterns in the country-level analysis. The composition of capital inflows matters: net other inflows, and sometimes net portfolio inflows, are linked with rapid credit growth, but not net FDI inflows.

\section{Discussion: Demand Boosts or Supply Expansions?}

The analysis so far has established positive linkages between capital inflows and credit growth. A related issue to investigate is whether demand- or supply-side factors drive these linkages. To be specific, on the one hand, capital inflows may boost asset prices (Hernandez and Landerretche, 1999; Jansen, 2003; Sa and Wieladek, 2010; Kim and Yang, 2011; Olaberria, 2011; Vasquez-Ruiz, 2012), which enhances firm value, improve balance sheets, and decrease the premium for external financing, and, as a result, increase the demand for credit. On the other hand, capital inflows may push domestic banks to decrease lending

\footnotetext{
${ }^{20}$ Since the range of control variables is not as wide as dependent variables, we choose the 1 percent level for the control variables. Dropping the top and bottom 5 percent observations of $Z$-score and the ratio of the sum of net income and depreciation to total assets yield similar results.
} 
standards and issue more credit in response to increased competition (Dell'Ariccia and Marquez, 2006; Dell'Ariccia, Igan, and Laeven, 2012).

One implication of the demand-side channel is that for firms that experience a larger increase in net equity or collateral values, the impact of capital inflows on credit should be more evident. $^{21}$ Therefore, we can add a term interacting capital inflows with the change in net equity or collateral values into Equation (2) to see whether the demand-side channel plays an important role in corporate credit growth. ${ }^{22}$ If the coefficient on this interaction term is significantly positive, it indicates a significant role for demand-side factors.

To investigate the supply-side channel, the idea is to exploit the cross-country differentiation in bank soundness indicators. Domestic banks are the main provider of credit and their health greatly affects credit availability. When domestic banks are not healthy, firms face tighter credit constraints. Capital inflows relieve these constraints and boost credit growth. By contrast, when the domestic banking sector is in good shape, credit constraints are not as severe. Capital inflows have a more modest effect on credit growth in this case because the domestic banking system has already provided adequate credit. To empirically implement this reasoning, we divide the sample into two subsamples based on the median value of various indicators: capital adequacy ratio (the ratio of capital and reserves to total assets), asset liquidity (the ratio of liquid assets to time deposits and other short-term funding), Zscore (the sum of return on assets and equity/assets divided by the standard deviation of return on assets), non-performing-loan ratio (the ratio of non-performing loans to total loans). Then we run regressions based on Equation (1) in the two subsamples separately. If capital inflows boost credit growth significantly in the subsample with lower capital adequacy ratio, lower asset liquidity, lower $Z$-score, and higher non-performing-loan ratio but plays a minor role in the subsample with higher capital adequacy ratio, higher asset liquidity, higher $Z$ score and lower non-performing-loan ratio, this is consistent with supply-side forces being at work.

We present the empirical results on the demand-side channel in Table 8. Regardless of the set of controls, net other inflows boost credit growth for firms that have experienced a greater change in equity value or tangible asset value. ${ }^{23}$ This is consistent with our predictions: capital inflows, especially net other inflows, may be pushing up asset prices, decrease the premium for external financing, and enhance the demand for credit.

The empirical results on the supply-side channel are reported in Table 9. As expected, the link between capital inflows and credit growth is stronger in the subsample with lower capital adequacy ratio, lower asset liquidity, lower $Z$-score, and higher non-performing-loan ratio.

\footnotetext{
${ }^{21}$ Systematic cross-country household-level data is not readily available, so we seek clues to an answer using firm-level data.

${ }^{22}$ To avoid multicollinearity and for ease of interpretation, we drop the interaction term of capital inflows and the $R Z$ index from the specification.

${ }^{23}$ In Bernanke and Gertler (1989), net equity value is negatively correlated with the premium for external financing. The amount of tangible assets determines collateral value, an important aspect to consider when granting loans.
} 
Moreover, the significance of different kinds of inflows differs in different subsamples. In the subsample with higher capital adequacy ratio, only the coefficient on net other inflows is significant. In comparison, the coefficients on all kinds of capital inflows are significant in the subsample with lower capital adequacy ratio. Furthermore, the coefficient before portfolio inflows is significant in the subsample with lower asset liquidity, lower $Z$-score, and higher non-performing-loan ratio, but not in the subsample with higher asset liquidity, higher $Z$-score, and lower non-performing-loan ratio. These results demonstrate that supply-side factors may be relevant in establishing the link from capital inflows to credit growth.

All in all, these findings suggest that both demand and supply channels are at work. More vigorous investigation of this issue is left for future research.

\section{CONClusion}

Empirical analysis based on a sample of 33 countries covering the period 1980-2011 demonstrates that capital inflows boost credit growth and increase the likelihood of credit booms for both the household sector and the corporate sector. The composition of capital inflows matters: while net other inflows are significantly associated with higher credit growth rates and credit booms for both the household sector and the corporate sector, net FDI inflows are not significantly connected with credit developments (except for corporate sector credit booms but even there the results are only marginally significant). Net portfolio inflows fall in between with a significant positive association detected in both household and corporate credit booms.

Firm-level evidence from the same set of countries lends further support for these findings. Net other inflows, but not net FDI inflows, are related to more rapid credit growth for firms that rely more heavily on external financing.

These linkages operate differently depending on financial system characteristics, although the composition of inflows continues to be important. Net other inflows are always linked to rapid credit growth while net portfolio inflows are associated with faster household credit growth only in countries with more advanced banking sectors and with faster corporate credit growth in less developed stock markets and less market-based financial systems. 


\section{References}

Abiad, A., G. Dell'Ariccia, and B. Li, 2011, "Creditless Recoveries," IMF Working Paper No. $11 / 58$.

Aizenman, J., and Y. Jinjarak, 2009, "Current Account Patterns and National Real Estate Markets," Journal of Urban Economics, Vol. 66, No. 2, pp. 75-89.

Beck, T., A. Demirguc-Kunt, and R. Levine, 2000, "A New Database on Financial Development and Structure," World Bank Economic Review, Vol. 14, pp. 597-605.

Beck, T., and R. Levine, 2002, "Industry Growth and Capital Allocation: Does Having a Market or Bank-Based System Matter?” Journal of Financial Economics, Vol. 64, pp. 147-180.

Bernanke, B., and M. Gertler, 1989, "Agency Costs, Net Worth, and Business Fluctuations," American Economic Review, Vol. 79, No. 1, pp. 14-31.

Bruno, V., and H. Shin, 2013, "Capital Flows, Cross-Border Banking and Global Liquidity," mimeo, Princeton University.

Calderon, C., and M. Kubota, 2012, "Gross Capital Inflows, Credit Booms and Crises," World Bank Policy Research Working Paper No. WPS6270.

Chinn, M., and H. Ito, 2008, "A New Measure of Financial Openness," Journal of Comparative Policy Analysis, Vol. 10, pp. 307-320.

Dell'Ariccia, G., and R. Marquez, 2006, "Lending Booms and Lending Standards," Journal of Finance, Vol. 61, No. 5, pp. 2511-2546.

Dell'Ariccia, G., D. Igan, L. Laeven, and H. Tong, 2012, "Policies for Macrofinancial Stability: How to Deal with Credit Booms," IMF Staff Discussion Note 12/06, June.

Dell'Ariccia G., D. Igan, and L. Laeven, 2012, "Credit Booms and Lending Standards: Evidence from the Subprime Mortgage Market," Journal of Money, Credit and Banking, Vol. 44, Issue 2-3, pp. 367-384.

Dembiermont, C., M. Drehmann, and S. Muksakunratana, 2013, "How Much does the Private Sector Really Borrow? A New Database for Total Credit to the Private Nonfinancial Sector," BIS Quarterly Review, March 2013, pp. 65-81.

Djankov, S., C. McLiesh, and A. Shleifer, 2007, "Private Credit in 129 Countries," Journal of Financial Economics, Vol. 84, No. 2, pp. 299-329.

Elekdag, S., and Y. Wu, 2011, “Rapid Credit Growth: Boon or Boom-Bust?” IMF Working Paper No. 11/241. 
Gourinchas, P., R., Valdes, and O. Landerretche, 2001, "Lending Booms: Latin America and the World," NBER Working Paper 8249.

Hernandez, L., and O. Landerretche, 1999, "Capital Inflows, Credit Booms and Macroeconomic Vulnerability: the Cross Country Experience," Money Affairs, Vol. 12, No. 1, pp. 1-69.

Ilzetzki, E., C. Reinhart, and K. Rogoff, 2010, "Exchange Rate Arrangements into the 21st Century: Will the Anchor Currency Hold?" unpublished manuscript.

Jansen, W. J., 2003, "What do Capital Inflows Do? Dissecting the Transmission Mechanism for Thailand: 1980-1996," Journal of Macroeconomics, Vol. 25, No. 4, pp. 457-480.

Kim, S. and D. Yang, 2011, "The Impact of Capital Inflows on Asset Prices in Emerging Asian Economies: Is Too Much Money Chasing Too Little Good?” Open Economies Review, Vol. 22, Issue 2, pp. 293-315.

Laibson, D., and J. Mollerstrom, 2010, "Capital Flows, Consumption Booms and Asset Bubbles: A Behavioral Alternative to the Savings Glut Hypothesis," Economic Journal, Vol. 120, pp. 354-374.

Lane, P., and P. Mcquade, 2013, "Domestic Credit Growth and International Capital Flows," European Central Bank Working Paper No. 1566.

Levine, R., 1997, "Financial Development and Economic Growth: Views and Agenda," Journal of Economic Literature, Vol. 35, No. 2, pp. 688-726.

Magud, N., C. Reinhart, and E. Vesperoni, 2012, "Capital Inflows, Exchange Rate Flexibility, and Credit Booms," IMF Working Paper No. 12/41.

Mendoza, E., and M. Terrones, 2012, "An Anatomy of Credits Booms and Their Demise," The Chilean Economy, Vol. 15, No. 2, pp. 4-32.

Myers, S., 1977, "Determinants of Corporate Borrowing," Journal of Financial Economics, Vol. 5, pp. 147-175.

Olaberria, E., 2011, "Capital Inflows and Asset Price Appreciation: Evidence from a Panel of Countries," Central Bank of Chile Working Paper No. 675.

Rajan, R., and L. Zingales, 1995, "What do We Know about Capital Structure? Some Evidence from International Data," Journal of Finance, Vol. 50, No. 5, pp. 14211460.

Rajan, R., and L. Zingales, 1998, "Financial Dependence and Growth," American Economic Review, Vol. 88, No. 3, pp. 559-586. 
Reinhart, C., and K. Rogoff, 2004, "The Modern History of Exchange Rate Arrangements: A Reinterpretation," Quarterly Journal of Economics, Vol. 119, No. 1, pp. 1-48.

Sa, F., and T. Wieladek, 2010, "Monetary Policy, Capital Inflows and the Housing Boom," Bank of England Working Paper No. 405.

Sa, S., 2006, "Capital Flows and Credit Booms in Emerging Market Economies," Financial Stability Review, Vol. 9, pp. 49-66.

Sa, F. P. Towbin, and T. Wieladek, 2014, "Capital Inflows, Financial Structure, and Housing Booms," Journal of the European Economic Association, Vol. 12, No. 2, pp. 522546.

Schularick, M., and A. M. Taylor, 2012, "Credit Booms Gone Bust: Monetary Policy, Leverage Cycles, and Financial Crises: 1870-2008," American Economic Review, Vol. 102, No. 2, pp. 1029-1061.

Tan, Z., S. Wei, Y. Yao, and Y. Zhao, 2013, "Financial Structure, Corporate Savings and Current Account Imbalances," China Center for Economic Research Working Paper No. E2013003.

Tong, H., and S. Wei, 2011, "The Composition Matters: Capital Inflows and Liquidity Crunch During a Global Economic Crisis," Review of Financial Studies, Vol. 24, pp. 2023-2052.

Vasquez-Ruiz, H., 2012, "The Link between Foreign Capital Flows and Housing Prices: A Panel Data Estimation," unpublished manuscript. 
Table 1. Summary Statistics for Key Variables

\begin{tabular}{|c|c|c|c|c|}
\hline \multicolumn{5}{|c|}{ Panel A: Macro-Level Variables } \\
\hline Variables & Mean & Std. & Min & $\operatorname{Max}$ \\
\hline Growth of Credit to Household Sector to GDP (\%) & 5.85 & 27.70 & -60.89 & 637.03 \\
\hline Household Credit Boom (dummy) & 0.12 & 0.32 & 0 & 1 \\
\hline Growth of Credit to Non-financial Corporations to GDP (\%) & 1.66 & 6.44 & -23.49 & 28.16 \\
\hline Corporate Credit Boom (dummy) & 0.04 & 0.20 & 0 & 1 \\
\hline Net Capital Inflows to GDP (\%) & 0.50 & 5.41 & -22.35 & 21.56 \\
\hline Net FDI Inflows to GDP (\%) & 0.14 & 3.51 & -22.69 & 15.15 \\
\hline Net Portfolio Inflows to GDP (\%) & 0.01 & 6.59 & -26.68 & 54.93 \\
\hline Net Other Inflows to GDP (\%) & 0.35 & 6.32 & -60.16 & 48.15 \\
\hline Log Real GDP Per Capita in National Currency & 11.26 & 2.09 & 6.81 & 16.89 \\
\hline Real GDP Growth Rate (\%) & 2.92 & 3.10 & -10.51 & 14.78 \\
\hline Broad Money to GDP (\%) & 87.84 & 55.86 & 17.67 & 416.18 \\
\hline Inflation $(\%)$ & 5.26 & 11.43 & -3.95 & 104.54 \\
\hline Deposit Interest Rate $(\%)$ & 7.04 & 10.20 & 0.00 & 105.52 \\
\hline Growth of Nominal Exchange Rate (National Currency /\$, \%) & 1.90 & 14.77 & -29.35 & 170.93 \\
\hline Exchange Rate Regime Coarse Classification & 2.37 & 1.19 & 1 & 5 \\
\hline Import and Export to GDP (\%) & 84.88 & 74.27 & 16.21 & 446.29 \\
\hline Capital Account Openness (Chinn-Ito Index) & 1.60 & 1.22 & -1.86 & 2.44 \\
\hline Sum of Market Capitalization and Private Credit to GDP (\%) & 163.36 & 102.09 & 16.40 & 706.34 \\
\hline Log of Stock Market Capitalization to Private Credit Ratio & -0.34 & 0.76 & -3.20 & 1.57 \\
\hline \multicolumn{5}{|c|}{ Panel B: Firm-Level Variables } \\
\hline Variables & Mean & Std. & Min & $\operatorname{Max}$ \\
\hline Growth Rate of Total Debts/(Total Debts+Equity) (\%) & 7.20 & 65.94 & -100 & 432.68 \\
\hline Growth Rate of Total Debts/Total Asset (\%) & 8.56 & 73.07 & -100 & 468.72 \\
\hline RZ Index & -0.06 & 1.94 & -29.47 & 10.65 \\
\hline Property, Plant and Equipment to Total Asset (\%) & 30.39 & 21.74 & 0 & 98.64 \\
\hline Receivables and Inventory to Total Asset (\%) & 33.86 & 20.24 & 0 & 91.58 \\
\hline Sum of Market Capitalization and Total Debts to Total Asset & 1.30 & 1.54 & 0.09 & 50.00 \\
\hline (Market capitalization+Asset-Equity) to Total Asset & 1.59 & 1.38 & 0.26 & 23.94 \\
\hline Earnings before Interest and Tax to Total Asset & 0.02 & 0.27 & -26.22 & 0.68 \\
\hline Log Sales & 12.19 & 2.11 & 1.39 & 18.00 \\
\hline Log Total Assets & 12.32 & 1.96 & 2.94 & 18.15 \\
\hline Interest Expense to Net Income & 0.19 & 1.22 & -81.27 & 26.49 \\
\hline Z-score & 2.64 & 4.53 & -304.46 & 241.73 \\
\hline Cash and Investment to Total Asset (\%) & 14.09 & 15.14 & 0 & 99.55 \\
\hline Sum of Net Income and Depreciation to Total Asset (\%) & 3.08 & 27.14 & -2769.3 & 49.48 \\
\hline $\begin{array}{l}\text { Notes: Top and bottom } 1 \text { percent observations of firm-level variables are } \\
3.107 * Z 3+0.420 * Z 4+0.998 * Z 5 . Z 1 \text { is working capital to total asset. } Z \\
\text { total asset. } Z 4 \text { is market value of equity to book value of total liabilities. } \\
\text { dependence on external finance and is calculated year by year following } \\
\text { Dependence on external finance }=(\text { Capital expenditures-cash flow }) / \text { capit } \\
\text { operations }+ \text { decrease in inventories }+ \text { decrease in receivables }+ \text { increase in }\end{array}$ & trized. & $\begin{array}{l}\text { ore }=0 . \\
\text { ngs to } t\end{array}$ & $\begin{array}{l}7 * \mathrm{Z} 1+0 \\
1 \text { asset. } \mathrm{Z}\end{array}$ & $\begin{array}{l}7 * \mathrm{Z2}+ \\
\text { s EBIT to } \\
\text { sed on the } \\
\text { (1998). } \\
\text { om }\end{array}$ \\
\hline
\end{tabular}


Table 2. Capital Inflows and Credit Growth: Baseline Results

\begin{tabular}{|c|c|c|c|c|c|c|c|c|}
\hline & \multicolumn{4}{|c|}{ Household Sector } & \multicolumn{4}{|c|}{ Corporate Sector } \\
\hline & \multicolumn{2}{|c|}{$\begin{array}{l}\text { Growth Rate of } \\
\text { Credit to GDP } \\
\end{array}$} & \multicolumn{2}{|c|}{$\begin{array}{l}\text { Credit } \\
\text { Boom } \\
\end{array}$} & \multicolumn{2}{|c|}{$\begin{array}{l}\text { Growth Rate of } \\
\text { Credit to GDP } \\
\end{array}$} & \multicolumn{2}{|c|}{$\begin{array}{l}\text { Credit } \\
\text { Boom }\end{array}$} \\
\hline & $(1)$ & $(2)$ & $(3)$ & $(4)$ & $(5)$ & $(6)$ & $(7)$ & $(8)$ \\
\hline Net capital inflows & $0.337^{* *}$ & & $0.010^{* *}$ & & $0.252^{* *}$ & & $0.007^{* *}$ & \\
\hline to GDP ratio & $(0.140)$ & & $(0.005)$ & & $(0.100)$ & & $(0.003)$ & \\
\hline $\begin{array}{l}\text { Net FDI inflows } \\
\text { to GDP ratio }\end{array}$ & & $\begin{array}{c}0.102 \\
(0.180)\end{array}$ & & $\begin{array}{c}0.007 \\
(0.005)\end{array}$ & & $\begin{array}{c}0.082 \\
(0.150)\end{array}$ & & $\begin{array}{l}0.007 * \\
(0.004)\end{array}$ \\
\hline $\begin{array}{l}\text { Net portfolio inflows } \\
\text { to GDP ratio }\end{array}$ & & $\begin{array}{l}0.329^{*} \\
(0.160)\end{array}$ & & $\begin{array}{c}0.011^{* *} \\
(0.004)\end{array}$ & & $\begin{array}{c}0.161 \\
(0.110)\end{array}$ & & $\begin{array}{l}0.008 * * \\
(0.004)\end{array}$ \\
\hline $\begin{array}{l}\text { Net other inflows } \\
\text { to GDP ratio }\end{array}$ & & $\begin{array}{l}0.380 * * * \\
(0.130)\end{array}$ & & $\begin{array}{c}0.010^{* *} \\
(0.005)\end{array}$ & & $\begin{array}{c}0.341 * * * \\
(0.090)\end{array}$ & & $\begin{array}{l}0.006^{* *} \\
(0.003)\end{array}$ \\
\hline $\begin{array}{l}\text { Log real GDP } \\
\text { per capita }\end{array}$ & $\begin{array}{l}-47.070 \\
(32.600)\end{array}$ & $\begin{array}{l}-49.660 \\
(32.100)\end{array}$ & $\begin{array}{c}-1.689 * * \\
(0.780)\end{array}$ & $\begin{array}{c}-1.696^{* *} \\
(0.780)\end{array}$ & $\begin{array}{c}24.980 \\
(19.900)\end{array}$ & $\begin{array}{c}19.650 \\
(19.500)\end{array}$ & $\begin{array}{c}0.557 \\
(0.600)\end{array}$ & $\begin{array}{c}0.603 \\
(0.600)\end{array}$ \\
\hline $\begin{array}{l}\text { Square of log real GDP } \\
\text { per capita }\end{array}$ & $\begin{array}{c}1.494 \\
(0.940)\end{array}$ & $\begin{array}{l}1.578^{*} \\
(0.930)\end{array}$ & $\begin{array}{l}0.051 * * \\
(0.024)\end{array}$ & $\begin{array}{l}0.051^{* *} \\
(0.024)\end{array}$ & $\begin{array}{l}-0.545 \\
(0.580)\end{array}$ & $\begin{array}{l}-0.376 \\
(0.560)\end{array}$ & $\begin{array}{l}-0.017 \\
(0.019)\end{array}$ & $\begin{array}{l}-0.019 \\
(0.019)\end{array}$ \\
\hline Real GDP growth rate & $\begin{array}{l}1.426^{*} \\
(0.820)\end{array}$ & $\begin{array}{l}1.409 * \\
(0.830)\end{array}$ & $\begin{array}{c}0.019 * * * \\
(0.005)\end{array}$ & $\begin{array}{c}0.019 * * * \\
(0.005)\end{array}$ & $\begin{array}{c}0.218 \\
(0.190)\end{array}$ & $\begin{array}{c}0.191 \\
(0.190)\end{array}$ & $\begin{array}{c}0.001 \\
(0.004)\end{array}$ & $\begin{array}{c}0.001 \\
(0.004)\end{array}$ \\
\hline $\begin{array}{l}\text { Broad money to } \\
\text { GDP ratio }\end{array}$ & $\begin{array}{l}-0.077^{*} \\
(0.043)\end{array}$ & $\begin{array}{c}-0.086^{* *} \\
(0.041)\end{array}$ & $\begin{array}{l}0.0004 \\
(0.001)\end{array}$ & $\begin{array}{l}0.0004 \\
(0.001)\end{array}$ & $\begin{array}{l}-0.007 \\
(0.031)\end{array}$ & $\begin{array}{l}-0.022 \\
(0.021)\end{array}$ & $\begin{array}{l}-0.001 \\
(0.001)\end{array}$ & $\begin{array}{l}-0.0004 \\
(0.001)\end{array}$ \\
\hline Inflation & $\begin{array}{l}-0.382 \\
(0.260)\end{array}$ & $\begin{array}{l}-0.392 \\
(0.250)\end{array}$ & $\begin{array}{c}-0.011^{* * *} \\
(0.004)\end{array}$ & $\begin{array}{c}-0.011 * * * \\
(0.004)\end{array}$ & $\begin{array}{l}-0.013 \\
(0.120)\end{array}$ & $\begin{array}{l}-0.039 \\
(0.130)\end{array}$ & $\begin{array}{c}0.007 \\
(0.005)\end{array}$ & $\begin{array}{c}0.007 \\
(0.005)\end{array}$ \\
\hline Deposit interest rate & $\begin{array}{l}1.248^{*} \\
(0.660)\end{array}$ & $\begin{array}{l}1.248^{*} \\
(0.650)\end{array}$ & $\begin{array}{c}0.021^{* * *} \\
(0.005)\end{array}$ & $\begin{array}{c}0.020^{* * *} \\
(0.005)\end{array}$ & $\begin{array}{l}-0.119 \\
(0.190)\end{array}$ & $\begin{array}{l}-0.104 \\
(0.200)\end{array}$ & $\begin{array}{l}-0.010^{*} \\
(0.006)\end{array}$ & $\begin{array}{l}-0.011^{*} \\
(0.006)\end{array}$ \\
\hline $\begin{array}{c}\text { Change of nominal } \\
\text { exchange rate }\end{array}$ & $\begin{array}{l}-0.168 \\
(0.126)\end{array}$ & $\begin{array}{l}-0.165 \\
(0.126)\end{array}$ & $\begin{array}{l}-0.004 * \\
(0.002)\end{array}$ & $\begin{array}{l}-0.004 * \\
(0.002)\end{array}$ & $\begin{array}{c}0.005 \\
(0.057)\end{array}$ & $\begin{array}{c}0.009 \\
(0.055)\end{array}$ & $\begin{array}{c}0.001 \\
(0.001)\end{array}$ & $\begin{array}{c}0.001 \\
(0.001)\end{array}$ \\
\hline Exchange rate regime & $\begin{array}{c}1.929 \\
(2.200)\end{array}$ & $\begin{array}{c}1.997 \\
(2.200)\end{array}$ & $\begin{array}{l}-0.018 \\
(0.054)\end{array}$ & $\begin{array}{l}-0.017 \\
(0.053)\end{array}$ & $\begin{array}{c}-2.172 * * \\
(0.820)\end{array}$ & $\begin{array}{c}-2.054 * * * \\
(0.720)\end{array}$ & $\begin{array}{c}0.004 \\
(0.010)\end{array}$ & $\begin{array}{c}0.003 \\
(0.010)\end{array}$ \\
\hline $\begin{array}{l}\text { Import and export } \\
\text { to GDP ratio }\end{array}$ & $\begin{array}{c}0.023 \\
(0.065)\end{array}$ & $\begin{array}{c}0.023 \\
(0.062)\end{array}$ & $\begin{array}{c}0.001 \\
(0.002)\end{array}$ & $\begin{array}{c}0.001 \\
(0.002)\end{array}$ & $\begin{array}{l}-0.012 \\
(0.040)\end{array}$ & $\begin{array}{l}-0.015 \\
(0.033)\end{array}$ & $\begin{array}{c}0.000 \\
(0.001)\end{array}$ & $\begin{array}{c}0.000 \\
(0.001)\end{array}$ \\
\hline $\begin{array}{l}\text { Capital account } \\
\text { openness }\end{array}$ & $\begin{array}{l}4.762 * \\
(2.630)\end{array}$ & $\begin{array}{l}4.557 * \\
(2.690)\end{array}$ & $\begin{array}{l}-0.009 \\
(0.021)\end{array}$ & $\begin{array}{l}-0.011 \\
(0.020)\end{array}$ & $\begin{array}{c}0.621 \\
(0.560)\end{array}$ & $\begin{array}{c}0.332 \\
(0.550)\end{array}$ & $\begin{array}{c}0.009 \\
(0.027)\end{array}$ & $\begin{array}{c}0.011 \\
(0.027)\end{array}$ \\
\hline Observations & 604 & 604 & 604 & 604 & 604 & 604 & 604 & 604 \\
\hline
\end{tabular}

Notes: The sample period is 1980-2011. Country and year fixed effects are included in all regressions. All control variables are lagged one period. Credit boom is a dummy variable indicating whether a country is experiencing a credit boom in a given year. The identification method for credit booms are discussed in the text. Exchange rate regime is from Reinhart and Rogoff (2004)'s coarse classification. Utilization of the fine classification yields similar results. Controlling for lending interest rate instead of deposit interest rate obtains similar results for capital flows although the sample size is reduced due to data availability. Capital account openness is measured by the Chinn-Ito index. Robust standard errors are in parentheses. $* * *, * *$, and $*$ indicate significance level at $1 \%, 5 \%$ and $10 \%$, respectively. 
Table 3. Capital Inflows and Household Credit Growth: Role of the Financial System

\begin{tabular}{|c|c|c|c|c|c|}
\hline & \multirow[b]{2}{*}{$\begin{array}{l}\text { Overall } \\
\text { (1) }\end{array}$} & \multicolumn{2}{|c|}{ Financial Development } & \multicolumn{2}{|c|}{ Financial Structure } \\
\hline & & $\begin{array}{l}\text { High } \\
(2)\end{array}$ & $\begin{array}{c}\text { Low } \\
(3)\end{array}$ & $\begin{array}{l}\text { High } \\
(4)\end{array}$ & $\begin{array}{c}\text { Low } \\
(5)\end{array}$ \\
\hline $\begin{array}{l}\text { Net FDI inflows } \\
\text { to GDP ratio }\end{array}$ & $\begin{array}{l}-0.044 \\
(0.171)\end{array}$ & $\begin{array}{l}0.060 \\
(0.084)\end{array}$ & $\begin{array}{c}0.128 \\
(0.712)\end{array}$ & $\begin{array}{l}-0.212 \\
(0.496)\end{array}$ & $\begin{array}{l}-0.174 \\
(0.226)\end{array}$ \\
\hline $\begin{array}{l}\text { Net portfolio inflows } \\
\text { to GDP ratio }\end{array}$ & $\begin{array}{c}0.217 \\
(0.159)\end{array}$ & $\begin{array}{l}0.180^{* * *} \\
(0.073)\end{array}$ & $\begin{array}{c}0.687 \\
(0.812)\end{array}$ & $\begin{array}{c}0.390 \\
(0.402)\end{array}$ & $\begin{array}{c}0.042 \\
(0.165)\end{array}$ \\
\hline $\begin{array}{l}\text { Net other inflows } \\
\text { to GDP ratio }\end{array}$ & $\begin{array}{l}0.280^{*} \\
(0.146)\end{array}$ & $\begin{array}{c}0.190^{* *} \\
(0.081)\end{array}$ & $\begin{array}{l}0.857^{*} \\
(0.490)\end{array}$ & $\begin{array}{c}0.269 \\
(0.436)\end{array}$ & $\begin{array}{c}0.229 \\
(0.164)\end{array}$ \\
\hline Log real GDP per capita & $\begin{array}{l}-79.408^{*} \\
(44.457)\end{array}$ & $\begin{array}{l}-23.571 \\
(33.305)\end{array}$ & $\begin{array}{l}-161.027^{*} \\
(84.815)\end{array}$ & $\begin{array}{l}-55.420 \\
(99.758)\end{array}$ & $\begin{array}{l}-20.857 \\
(32.459)\end{array}$ \\
\hline $\begin{array}{l}\text { Square of log real GDP } \\
\text { per capita }\end{array}$ & $\begin{array}{r}2.998^{* *} \\
(1.401)\end{array}$ & $\begin{array}{c}2.431 \\
(1.501)\end{array}$ & $\begin{array}{l}5.382 * \\
(2.880)\end{array}$ & $\begin{array}{l}2.547 \\
(3.335)\end{array}$ & $\begin{array}{c}0.885 \\
(1.085)\end{array}$ \\
\hline Real GDP growth rate & $\begin{array}{c}1.700 \\
(1.037)\end{array}$ & $\begin{array}{c}0.122 \\
(0.134)\end{array}$ & $\begin{array}{c}2.819 \\
(1.771)\end{array}$ & $\begin{array}{l}1.389^{*} \\
(0.741)\end{array}$ & $\begin{array}{l}0.662 * * \\
(0.316)\end{array}$ \\
\hline Broad money to GDP ratio & $\begin{array}{l}-0.104 * \\
(0.053)\end{array}$ & $\begin{array}{l}0.053^{*} \\
(0.030)\end{array}$ & $\begin{array}{l}-0.214 \\
(0.164)\end{array}$ & $\begin{array}{l}-0.054 \\
(0.109)\end{array}$ & $\begin{array}{l}-0.099^{*} \\
(0.048)\end{array}$ \\
\hline Inflation & $\begin{array}{c}-0.566^{* *} \\
(0.239)\end{array}$ & $\begin{array}{c}0.202 \\
(0.362)\end{array}$ & $\begin{array}{l}-0.887^{*} \\
(0.485)\end{array}$ & $\begin{array}{c}0.399 \\
(0.352)\end{array}$ & $\begin{array}{c}-0.558^{* *} \\
(0.225)\end{array}$ \\
\hline Deposit interest rate & $\begin{array}{l}1.317^{* *} \\
(0.584)\end{array}$ & $\begin{array}{l}-0.292 \\
(0.331)\end{array}$ & $\begin{array}{l}1.628^{* *} \\
(0.757)\end{array}$ & $\begin{array}{c}1.048 \\
(1.067)\end{array}$ & $\begin{array}{l}0.929^{*} \\
(0.489)\end{array}$ \\
\hline $\begin{array}{l}\text { Change of nominal } \\
\text { exchange rate }\end{array}$ & $\begin{array}{l}-0.138 \\
(0.112)\end{array}$ & $\begin{array}{l}-0.077 \\
(0.046)\end{array}$ & $\begin{array}{l}-0.087 \\
(0.178)\end{array}$ & $\begin{array}{l}-0.756 \\
(0.509)\end{array}$ & $\begin{array}{l}-0.248^{*} \\
(0.129)\end{array}$ \\
\hline Exchange rate regime & $\begin{array}{l}2.600 \\
(2.430)\end{array}$ & $\begin{array}{l}-0.231 \\
(0.961)\end{array}$ & $\begin{array}{c}4.016 \\
(3.847)\end{array}$ & $\begin{array}{l}20.834^{*} \\
(10.673)\end{array}$ & $\begin{array}{c}0.419 \\
(1.647)\end{array}$ \\
\hline $\begin{array}{l}\text { Import and export } \\
\text { to GDP ratio }\end{array}$ & $\begin{array}{c}0.003 \\
(0.075)\end{array}$ & $\begin{array}{c}-0.107 * * * \\
(0.022)\end{array}$ & $\begin{array}{c}0.029 \\
(0.236)\end{array}$ & $\begin{array}{l}-0.114 \\
(0.102)\end{array}$ & $\begin{array}{l}0.204^{*} \\
(0.113)\end{array}$ \\
\hline Capital account openness & $\begin{array}{l}5.743^{*} \\
(3.151)\end{array}$ & $\begin{array}{c}0.025 \\
(2.723)\end{array}$ & $\begin{array}{c}7.526 \\
(5.532)\end{array}$ & $\begin{array}{c}1.902 \\
(6.464)\end{array}$ & $\begin{array}{r}2.138^{* *} \\
(0.855)\end{array}$ \\
\hline Observations & 508 & 254 & 254 & 254 & 254 \\
\hline
\end{tabular}

Notes: The sample period is 1989-2011. The analysis is restricted to the sample where financial development and financial structure information is available. Country and year fixed effects are included in all regressions. All control variables are lagged one period. Financial development is the sum of stock market capitalization and private credit to GDP ratio. Financial structure is the log ratio of stock market capitalization to private credit. Columns (2) and (3) are based on high financial development group and low financial development group respectively, using the median value of financial development in the whole sample as cut-off. Columns (4) and (5) are based on more market-based group (high) and less market-based group (low) respectively, using the median value of financial structure in the whole sample as cut-off. Exchange rate regime is from Reinhart and Rogoff (2004)'s coarse classification. Utilization of the fine classification yields similar results. Controlling for lending interest rate instead of deposit interest rate obtains similar results for capital flows although the sample size is reduced due to data availability. Capital account openness is measured by the Chinn-Ito index. Robust standard errors are in parentheses. $* * *, * *$, and $*$ indicate significance level at $1 \%, 5 \%$ and $10 \%$, respectively. 
Table 4. Capital Inflows and Corporate Credit Growth: Role of the Financial System

\begin{tabular}{|c|c|c|c|c|c|}
\hline & \multirow[b]{2}{*}{$\begin{array}{l}\text { Overall } \\
(1)\end{array}$} & \multicolumn{2}{|c|}{ Financial Development } & \multicolumn{2}{|c|}{ Financial Structure } \\
\hline & & $\begin{array}{l}\text { High } \\
\text { (2) }\end{array}$ & $\begin{array}{l}\text { Low } \\
\text { (3) }\end{array}$ & $\begin{array}{l}\text { High } \\
(4)\end{array}$ & $\begin{array}{c}\text { Low } \\
(5)\end{array}$ \\
\hline \multirow{2}{*}{$\begin{array}{l}\text { Net FDI inflows } \\
\text { to GDP ratio }\end{array}$} & 0.025 & 0.057 & -0.070 & -0.091 & $0.332 * *$ \\
\hline & $(0.150)$ & $(0.171)$ & $(0.214)$ & $(0.122)$ & $(0.160)$ \\
\hline \multirow{2}{*}{$\begin{array}{l}\text { Net portfolio inflows } \\
\text { to GDP ratio }\end{array}$} & 0.157 & 0.089 & $0.388^{*}$ & 0.110 & $0.315 * *$ \\
\hline & $(0.110)$ & $(0.116)$ & $(0.225)$ & $(0.100)$ & $(0.130)$ \\
\hline \multirow{2}{*}{$\begin{array}{l}\text { Net other inflows } \\
\text { to GDP ratio }\end{array}$} & $0.315 * * *$ & $0.235 * *$ & $0.438 * *$ & $0.368 * * *$ & $0.381 * * *$ \\
\hline & $(0.091)$ & $(0.104)$ & $(0.168)$ & $(0.102)$ & $(0.128)$ \\
\hline \multirow[t]{2}{*}{ Log real GDP per capita } & 10.693 & -42.454 & 12.147 & -9.362 & 14.696 \\
\hline & $(20.104)$ & $(36.156)$ & $(43.056)$ & $(37.866)$ & $(26.674)$ \\
\hline \multirow{2}{*}{$\begin{array}{l}\text { Square of log real GDP } \\
\text { per capita }\end{array}$} & -0.058 & 2.480 & -0.086 & 0.333 & 0.157 \\
\hline & $(0.581)$ & $(1.847)$ & $(1.170)$ & $(0.877)$ & $(0.855)$ \\
\hline \multirow[t]{2}{*}{ Real GDP growth rate } & $0.303 *$ & 0.237 & 0.311 & 0.106 & 0.241 \\
\hline & $(0.170)$ & $(0.207)$ & $(0.291)$ & $(0.222)$ & $(0.194)$ \\
\hline \multirow[t]{2}{*}{ Broad money to GDP ratio } & -0.032 & 0.028 & $-0.115^{*}$ & $-0.062 * *$ & $-0.087 * * *$ \\
\hline & $(0.024)$ & $(0.022)$ & $(0.062)$ & $(0.029)$ & $(0.030)$ \\
\hline \multirow[t]{2}{*}{ Inflation } & -0.061 & -0.646 & -0.096 & $0.246^{*}$ & $-0.332 * *$ \\
\hline & $(0.148)$ & $(0.418)$ & $(0.165)$ & $(0.135)$ & $(0.160)$ \\
\hline \multirow[t]{2}{*}{ Deposit interest rate } & -0.150 & 0.336 & -0.160 & $-0.741 * * *$ & $0.361 * *$ \\
\hline & $(0.211)$ & $(0.376)$ & $(0.209)$ & $(0.241)$ & $(0.167)$ \\
\hline \multirow{2}{*}{$\begin{array}{l}\text { Change of nominal } \\
\text { exchange rate }\end{array}$} & 0.051 & 0.076 & 0.084 & $0.123 * *$ & 0.030 \\
\hline & $(0.057)$ & $(0.068)$ & $(0.067)$ & $(0.057)$ & $(0.071)$ \\
\hline \multirow[t]{2}{*}{ Exchange rate regime } & $-2.221 * * *$ & $-2.237 * *$ & $-1.717 * *$ & -1.858 & $-2.005 * * *$ \\
\hline & $(0.806)$ & $(0.903)$ & $(0.713)$ & $(1.485)$ & $(0.483)$ \\
\hline \multirow{2}{*}{$\begin{array}{l}\text { Import and export } \\
\text { to GDP ratio }\end{array}$} & -0.003 & 0.030 & -0.101 & 0.022 & -0.070 \\
\hline & $(0.034)$ & $(0.032)$ & $(0.107)$ & $(0.027)$ & $(0.056)$ \\
\hline \multirow[t]{2}{*}{ Capital account openness } & -0.370 & $-3.951 *$ & -0.370 & $-2.871 * *$ & 0.364 \\
\hline & $(0.610)$ & $(2.041)$ & $(0.639)$ & $(1.240)$ & $(0.460)$ \\
\hline Observations & 508 & 254 & 254 & 254 & 254 \\
\hline
\end{tabular}

Notes: The sample period is 1989-2011. The analysis is restricted to the sample whose financial development and financial structure information is available. Country and year fixed effects are included in all regressions. All control variables are lagged one period. Financial development is the sum of stock market capitalization and private credit to GDP ratio. Financial structure is the log ratio of stock market capitalization to private credit. Columns (2) and (3) are based on high financial development group and low financial development group respectively, using the median value of financial development in the whole sample as cut-off. Columns (4) and (5) are based on more market-based group (high) and less market-based group (low) respectively, using the median value of financial structure in the whole sample as cut-off. Exchange rate regime is from Reinhart and Rogoff (2004)'s coarse classification. Utilization of the fine classification yields similar results. Controlling for lending interest rate instead of deposit interest rate obtains similar results for capital flows although the sample size is reduced due to data availability. Capital account openness is measured by the Chinn-Ito index. Robust standard errors are in parentheses. $* * *, * *$, and $*$ indicate significance level at $1 \%, 5 \%$ and $10 \%$, respectively. 
Table 5. Capital Inflows and Firm-Level Credit Growth: Baseline Results

\begin{tabular}{|c|c|c|c|c|c|c|}
\hline \multirow[b]{2}{*}{$\mathrm{RZ}$ inde $\times \mathrm{FDI}$} & \multicolumn{3}{|c|}{ Growth of Leverage 1} & \multicolumn{3}{|c|}{ Growth of Leverage 2} \\
\hline & $\begin{array}{c}0.046 \\
(0.064)\end{array}$ & $\begin{array}{c}0.062 \\
(0.076)\end{array}$ & $\begin{array}{c}0.059 \\
(0.075)\end{array}$ & $\begin{array}{c}0.028 \\
(0.066)\end{array}$ & $\begin{array}{c}0.050 \\
(0.079)\end{array}$ & $\begin{array}{c}0.046 \\
(0.079)\end{array}$ \\
\hline $\mathrm{RZ}$ inde $\times \mathrm{FPI}$ & 0.022 & $0.050 * *$ & $0.048^{*}$ & 0.025 & 0.044 & 0.041 \\
\hline & $(0.020)$ & $(0.024)$ & $(0.024)$ & $(0.022)$ & $(0.027)$ & $(0.027)$ \\
\hline $\mathrm{RZ}$ inde $\times \mathrm{FOI}$ & $\begin{array}{l}0.036^{*} \\
(0.022)\end{array}$ & $\begin{array}{l}0.047^{*} \\
(0.025)\end{array}$ & $\begin{array}{l}0.045^{*} \\
(0.025)\end{array}$ & $\begin{array}{c}0.048^{* *} \\
(0.021)\end{array}$ & $\begin{array}{l}0.056^{* *} \\
(0.025)\end{array}$ & $\begin{array}{c}0.053 * * \\
(0.025)\end{array}$ \\
\hline $\begin{array}{l}\text { Property, plant and } \\
\text { equipment to assets ratio }\end{array}$ & $\begin{array}{l}-0.200^{* * *} \\
(0.024)\end{array}$ & $\begin{array}{l}-0.146^{* * *} \\
(0.023)\end{array}$ & $\begin{array}{c}-0.105^{* * * *} \\
(0.025)\end{array}$ & $\begin{array}{l}-0.325^{* * *} \\
(0.029)\end{array}$ & $\begin{array}{c}-0.330^{* * *} \\
(0.035)\end{array}$ & $\begin{array}{c}-0.271 * * * \\
(0.031)\end{array}$ \\
\hline $\begin{array}{l}\text { (Market capitalization+ } \\
\text { total debt) to assets ratio }\end{array}$ & $\begin{array}{l}-0.264 \\
(0.252)\end{array}$ & $\begin{array}{c}-5.188 * * * \\
(0.435)\end{array}$ & $\begin{array}{l}-5.200 * * * \\
(0.416)\end{array}$ & $\begin{array}{c}-1.497 * * * \\
(0.121)\end{array}$ & $\begin{array}{l}-1.551 * * * \\
(0.201)\end{array}$ & $\begin{array}{c}-1.628^{* * * *} \\
(0.204)\end{array}$ \\
\hline EBIT to assets ratio & $\begin{array}{l}15.703 * * * \\
(3.006)\end{array}$ & $\begin{array}{c}0.961 \\
(2.433)\end{array}$ & $\begin{array}{c}1.092 \\
(3.620)\end{array}$ & $\begin{array}{l}5.391 * * * \\
(0.547)\end{array}$ & $\begin{array}{l}-2.612 * * * \\
(0.665)\end{array}$ & $\begin{array}{c}-5.175 * * \\
(2.024)\end{array}$ \\
\hline Log sales & $\begin{array}{l}-3.238^{* * *} \\
(0.472)\end{array}$ & $\begin{array}{c}-3.373 * * * \\
(0.362)\end{array}$ & $\begin{array}{c}-3.070^{* * *} \\
(0.378)\end{array}$ & $\begin{array}{l}-2.418^{* * *} \\
(0.423)\end{array}$ & $\begin{array}{l}-2.976^{* * *} \\
(0.420)\end{array}$ & $\begin{array}{c}-2.634 * * * \\
(0.400)\end{array}$ \\
\hline $\begin{array}{l}\text { Interest expense } \\
\text { to net income ratio }\end{array}$ & & $\begin{array}{c}-0.609 * * * \\
(0.081)\end{array}$ & $\begin{array}{c}-0.652 * * * \\
(0.078)\end{array}$ & & $\begin{array}{c}-0.626^{* * *} \\
(0.087)\end{array}$ & $\begin{array}{c}-0.670 * * * \\
(0.085)\end{array}$ \\
\hline Z-score & & $\begin{array}{c}3.034 * * * \\
(0.250)\end{array}$ & $\begin{array}{c}2.973 * * * \\
(0.247)\end{array}$ & & $\begin{array}{c}0.996^{* * *} \\
(0.084)\end{array}$ & $\begin{array}{c}0.979 * * * \\
(0.081)\end{array}$ \\
\hline $\begin{array}{l}\text { Cash and short term } \\
\text { investment to assets ratio }\end{array}$ & & & $\begin{array}{c}0.141 * * * \\
(0.029)\end{array}$ & & & $\begin{array}{c}0.191 * * * \\
(0.047)\end{array}$ \\
\hline $\begin{array}{l}\text { Net income+depreciation } \\
\text { to assets ratio }\end{array}$ & & & $\begin{array}{l}-0.001 \\
(0.055)\end{array}$ & & & $\begin{array}{c}0.027 \\
(0.018)\end{array}$ \\
\hline $\begin{array}{l}\text { Net FDI inflows } \\
\text { to GDP ratio }\end{array}$ & $\begin{array}{c}0.064 \\
(0.160)\end{array}$ & $\begin{array}{c}0.014 \\
(0.168)\end{array}$ & $\begin{array}{c}0.007 \\
(0.168)\end{array}$ & $\begin{array}{l}-0.029 \\
(0.156)\end{array}$ & $\begin{array}{l}-0.086 \\
(0.167)\end{array}$ & $\begin{array}{l}-0.095 \\
(0.165)\end{array}$ \\
\hline $\begin{array}{l}\text { Net portfolio inflows } \\
\text { to GDP ratio }\end{array}$ & $\begin{array}{l}-0.037 \\
(0.069)\end{array}$ & $\begin{array}{l}-0.098 \\
(0.079)\end{array}$ & $\begin{array}{l}-0.103 \\
(0.080)\end{array}$ & $\begin{array}{c}0.001 \\
(0.065)\end{array}$ & $\begin{array}{l}-0.076 \\
(0.074)\end{array}$ & $\begin{array}{l}-0.082 \\
(0.073)\end{array}$ \\
\hline $\begin{array}{l}\text { Net other inflows } \\
\text { to GDP ratio }\end{array}$ & $\begin{array}{c}0.176^{* *} \\
(0.080)\end{array}$ & $\begin{array}{l}0.152^{*} \\
(0.089)\end{array}$ & $\begin{array}{c}0.143 \\
(0.090)\end{array}$ & $\begin{array}{c}0.234 * * * \\
(0.073)\end{array}$ & $\begin{array}{l}0.188^{* *} \\
(0.079)\end{array}$ & $\begin{array}{c}0.176^{* *} \\
(0.078)\end{array}$ \\
\hline RZ index & $\begin{array}{c}0.375 \\
(0.278)\end{array}$ & $\begin{array}{c}0.524 \\
(0.325)\end{array}$ & $\begin{array}{c}0.528 \\
(0.334)\end{array}$ & $\begin{array}{c}0.545 \\
(0.338)\end{array}$ & $\begin{array}{l}0.586^{*} \\
(0.309)\end{array}$ & $\begin{array}{l}0.579^{*} \\
(0.312)\end{array}$ \\
\hline Log real GDP per capita & $\begin{array}{c}-0.349 \\
(12.108)\end{array}$ & $\begin{array}{c}6.790 \\
(12.953)\end{array}$ & $\begin{array}{c}8.939 \\
(12.815)\end{array}$ & $\begin{array}{l}-12.147 \\
(11.754)\end{array}$ & $\begin{array}{l}-15.795 \\
(12.411)\end{array}$ & $\begin{array}{l}-15.097 \\
(12.779)\end{array}$ \\
\hline $\begin{array}{l}\text { Square of log real GDP } \\
\text { per capita }\end{array}$ & $\begin{array}{l}0.729^{*} \\
(0.412)\end{array}$ & $\begin{array}{c}0.380 \\
(0.459)\end{array}$ & $\begin{array}{c}0.292 \\
(0.458)\end{array}$ & $\begin{array}{l}1.232 * * * \\
(0.423)\end{array}$ & $\begin{array}{l}1.085^{* *} \\
(0.461)\end{array}$ & $\begin{array}{l}1.065^{* *} \\
(0.483)\end{array}$ \\
\hline Real GDP growth rate & $\begin{array}{c}0.350 * * * \\
(0.093)\end{array}$ & $\begin{array}{c}0.260^{* * *} \\
(0.090)\end{array}$ & $\begin{array}{c}0.287 * * * \\
(0.086)\end{array}$ & $\begin{array}{c}0.288 * * * \\
(0.085)\end{array}$ & $\begin{array}{c}0.113 \\
(0.088)\end{array}$ & $\begin{array}{l}0.138^{*} \\
(0.082)\end{array}$ \\
\hline $\begin{array}{l}\text { Broad Money to } \\
\text { GDP ratio }\end{array}$ & $\begin{array}{c}-0.050 * * * \\
(0.014)\end{array}$ & $\begin{array}{c}-0.088 * * * \\
(0.015)\end{array}$ & $\begin{array}{c}-0.078 * * * \\
(0.016)\end{array}$ & $\begin{array}{c}-0.057 * * * \\
(0.016)\end{array}$ & $\begin{array}{c}-0.091 * * * \\
(0.016)\end{array}$ & $\begin{array}{c}-0.082 * * * \\
(0.017)\end{array}$ \\
\hline Inflation & $\begin{array}{c}-0.406^{* * *} \\
(0.121)\end{array}$ & $\begin{array}{c}-0.580 * * * \\
(0.133)\end{array}$ & $\begin{array}{c}-0.542 * * * \\
(0.137)\end{array}$ & $\begin{array}{c}-0.385^{* * *} \\
(0.112)\end{array}$ & $\begin{array}{c}-0.632 * * * \\
(0.132)\end{array}$ & $\begin{array}{c}-0.612 * * * \\
(0.136)\end{array}$ \\
\hline Deposit interest rate & $\begin{array}{c}0.394 * * * \\
(0.119)\end{array}$ & $\begin{array}{c}0.568 * * * \\
(0.143)\end{array}$ & $\begin{array}{c}0.536 * * * \\
(0.147)\end{array}$ & $\begin{array}{c}0.449 * * * \\
(0.119)\end{array}$ & $\begin{array}{c}0.634 * * * \\
(0.155)\end{array}$ & $\begin{array}{c}0.622 * * * \\
(0.155)\end{array}$ \\
\hline $\begin{array}{l}\text { Change of nominal } \\
\text { exchange rate }\end{array}$ & $\begin{array}{c}0.074 * * * \\
(0.025)\end{array}$ & $\begin{array}{c}0.090 * * * \\
(0.027)\end{array}$ & $\begin{array}{c}0.093 * * * \\
(0.028)\end{array}$ & $\begin{array}{c}0.029 \\
(0.027)\end{array}$ & $\begin{array}{c}0.033 \\
(0.028)\end{array}$ & $\begin{array}{c}0.038 \\
(0.029)\end{array}$ \\
\hline Exchange rate regime & $\begin{array}{l}-1.542 * * * \\
(0.474)\end{array}$ & $\begin{array}{l}-0.155 \\
(0.510)\end{array}$ & $\begin{array}{l}-0.161 \\
(0.504)\end{array}$ & $\begin{array}{c}-1.807 * * * \\
(0.471)\end{array}$ & $\begin{array}{l}-0.506 \\
(0.531)\end{array}$ & $\begin{array}{l}-0.512 \\
(0.534)\end{array}$ \\
\hline $\begin{array}{l}\text { Import and export } \\
\text { to GDP ratio }\end{array}$ & $\begin{array}{c}-0.042 * * * \\
(0.015)\end{array}$ & $\begin{array}{l}-0.009 \\
(0.020)\end{array}$ & $\begin{array}{l}-0.014 \\
(0.021)\end{array}$ & $\begin{array}{l}-0.029 \\
(0.018)\end{array}$ & $\begin{array}{c}0.001 \\
(0.023)\end{array}$ & $\begin{array}{l}-0.003 \\
(0.023)\end{array}$ \\
\hline Capital account openness & $\begin{array}{c}3.347 * * * \\
(0.595)\end{array}$ & $\begin{array}{l}2.956 * * * \\
(0.647)\end{array}$ & $\begin{array}{l}2.956 * * * \\
(0.650)\end{array}$ & $\begin{array}{c}3.569 * * * \\
(0.603)\end{array}$ & $\begin{array}{c}3.205^{* * *} \\
(0.648)\end{array}$ & $\begin{array}{c}3.074 * * * \\
(0.661)\end{array}$ \\
\hline Observations & 212955 & 193440 & 189001 & 230377 & 209944 & 205268 \\
\hline
\end{tabular}


Table 6. Capital Inflows and Firm-Level Credit Growth: Alternative Controls

\begin{tabular}{|c|c|c|c|c|c|c|}
\hline \multirow[b]{2}{*}{$\mathrm{RZ}$ inde $\times \mathrm{FDI}$} & \multicolumn{3}{|c|}{ Growth of Leverage 1} & \multicolumn{3}{|c|}{ Growth of Leverage 2} \\
\hline & $\begin{array}{c}0.035 \\
(0.062)\end{array}$ & $\begin{array}{c}0.050 \\
(0.074)\end{array}$ & $\begin{array}{l}0.045 \\
(0.073)\end{array}$ & $\begin{array}{c}0.028 \\
(0.067)\end{array}$ & $\begin{array}{c}0.043 \\
(0.080)\end{array}$ & $\begin{array}{c}0.040 \\
(0.078)\end{array}$ \\
\hline $\mathrm{RZ}$ inde $\times \mathrm{FPI}$ & $\begin{array}{l}0.035 \\
(0.021)\end{array}$ & $\begin{array}{l}0.062 * * \\
(0.031)\end{array}$ & $\begin{array}{l}0.058^{*} \\
(0.029)\end{array}$ & $0.036^{*}$ & $\begin{array}{l}0.064 * * \\
(0.030)\end{array}$ & $\begin{array}{l}0.063 * * \\
(0.031)\end{array}$ \\
\hline $\mathrm{RZ}$ inde $\times \mathrm{FOI}$ & $\begin{array}{l}0.039^{*} \\
(0.022)\end{array}$ & $\begin{array}{l}0.049^{*} \\
(0.027)\end{array}$ & $\begin{array}{l}0.045^{*} \\
(0.027)\end{array}$ & $\begin{array}{l}0.048^{* *} \\
(0.020)\end{array}$ & $\begin{array}{c}0.060^{* *} \\
(0.026)\end{array}$ & $\begin{array}{c}0.057 * * \\
(0.026)\end{array}$ \\
\hline $\begin{array}{l}\text { Receivables and } \\
\text { inventory to assets ratio }\end{array}$ & $\begin{array}{c}-0.237 * * * \\
(0.034)\end{array}$ & $\begin{array}{c}-0.191 * * * \\
(0.035)\end{array}$ & $\begin{array}{c}-0.132 * * * \\
(0.036)\end{array}$ & $\begin{array}{c}-0.091 * * \\
(0.039)\end{array}$ & $\begin{array}{l}-0.043 \\
(0.039)\end{array}$ & $\begin{array}{c}0.023 \\
(0.034)\end{array}$ \\
\hline $\begin{array}{l}\text { (Market capitalization }+ \\
\text { assets-equity) to assets ratio }\end{array}$ & $\begin{array}{l}-0.091 \\
(0.272)\end{array}$ & $\begin{array}{l}-4.723 * * * \\
(0.490)\end{array}$ & $\begin{array}{l}-4.808^{* * * *} \\
(0.496)\end{array}$ & $\begin{array}{c}0.787 * * \\
(0.364)\end{array}$ & $\begin{array}{c}-3.184 * * * \\
(0.517)\end{array}$ & $\begin{array}{c}-3.369 * * * \\
(0.545)\end{array}$ \\
\hline EBIT to assets ratio & $\begin{array}{l}13.613 * * * \\
(2.266)\end{array}$ & $\begin{array}{c}0.771 \\
(2.098)\end{array}$ & $\begin{array}{c}1.098 \\
(3.834)\end{array}$ & $\begin{array}{c}7.380 * * * \\
(1.650)\end{array}$ & $\begin{array}{c}-3.979 * * \\
(1.883)\end{array}$ & $\begin{array}{c}1.352 \\
(4.044)\end{array}$ \\
\hline Log assets & $\begin{array}{l}-1.057 \\
(0.719)\end{array}$ & $\begin{array}{c}-1.749 * * * \\
(0.593)\end{array}$ & $\begin{array}{c}-1.484 * * \\
(0.613)\end{array}$ & $\begin{array}{l}-1.492 * * * \\
(0.555)\end{array}$ & $\begin{array}{c}-2.404 * * * \\
(0.492)\end{array}$ & $\begin{array}{c}-2.183 * * * \\
(0.513)\end{array}$ \\
\hline $\begin{array}{l}\text { Interest expense } \\
\text { to net income ratio }\end{array}$ & & $\begin{array}{c}-0.604 * * * \\
(0.085)\end{array}$ & $\begin{array}{c}-0.639 * * * \\
(0.081)\end{array}$ & & $\begin{array}{c}-0.764 * * * \\
(0.094)\end{array}$ & $\begin{array}{c}-0.791 * * * \\
(0.088)\end{array}$ \\
\hline Z-score & & $\begin{array}{c}2.394 * * * \\
(0.242)\end{array}$ & $\begin{array}{c}2.338 * * * \\
(0.238)\end{array}$ & & $\begin{array}{c}2.117 * * * \\
(0.206)\end{array}$ & $\begin{array}{c}2.105 * * * \\
(0.222)\end{array}$ \\
\hline $\begin{array}{l}\text { Cash and short term } \\
\text { investment to assets ratio }\end{array}$ & & & $\begin{array}{c}0.168^{* * *} \\
(0.026)\end{array}$ & & & $\begin{array}{c}0.188 * * * \\
(0.033)\end{array}$ \\
\hline $\begin{array}{l}\text { Net income }+ \text { depreciation } \\
\text { to assets ratio }\end{array}$ & & & $\begin{array}{l}-0.004 \\
(0.049)\end{array}$ & & & $\begin{array}{l}-0.063 \\
(0.046)\end{array}$ \\
\hline $\begin{array}{l}\text { Net FDI inflows } \\
\text { to GDP ratio }\end{array}$ & $\begin{array}{c}0.003 \\
(0.150)\end{array}$ & $\begin{array}{l}-0.044 \\
(0.159)\end{array}$ & $\begin{array}{l}-0.048 \\
(0.158)\end{array}$ & $\begin{array}{l}-0.050 \\
(0.150)\end{array}$ & $\begin{array}{l}-0.094 \\
(0.160)\end{array}$ & $\begin{array}{l}-0.093 \\
(0.159)\end{array}$ \\
\hline $\begin{array}{l}\text { Net portfolio inflows } \\
\text { to GDP ratio }\end{array}$ & $\begin{array}{l}-0.044 \\
(0.073)\end{array}$ & $\begin{array}{l}-0.097 \\
(0.084)\end{array}$ & $\begin{array}{l}-0.106 \\
(0.083)\end{array}$ & $\begin{array}{c}0.022 \\
(0.072)\end{array}$ & $\begin{array}{l}-0.019 \\
(0.083)\end{array}$ & $\begin{array}{l}-0.024 \\
(0.084)\end{array}$ \\
\hline $\begin{array}{l}\text { Net other inflows } \\
\text { to GDP ratio }\end{array}$ & $\begin{array}{l}0.147^{*} \\
(0.080)\end{array}$ & $\begin{array}{c}0.131 \\
(0.090)\end{array}$ & $\begin{array}{c}0.118 \\
(0.090)\end{array}$ & $\begin{array}{l}0.242 * * * \\
(0.079)\end{array}$ & $\begin{array}{c}0.239 * * * \\
(0.088)\end{array}$ & $\begin{array}{c}0.228 * * \\
(0.087)\end{array}$ \\
\hline $\mathrm{RZ}$ index & $\begin{array}{c}0.337 \\
(0.242)\end{array}$ & $\begin{array}{c}0.474 \\
(0.293)\end{array}$ & $\begin{array}{c}0.477 \\
(0.300)\end{array}$ & $\begin{array}{c}0.391 \\
(0.241)\end{array}$ & $\begin{array}{c}0.475 \\
(0.293)\end{array}$ & $\begin{array}{c}0.484 \\
(0.303)\end{array}$ \\
\hline Log real GDP per capita & $\begin{array}{c}1.006 \\
(12.731)\end{array}$ & $\begin{array}{c}6.297 \\
(13.454)\end{array}$ & $\begin{array}{c}6.434 \\
(13.350)\end{array}$ & $\begin{array}{c}4.491 \\
(11.154)\end{array}$ & $\begin{array}{c}10.318 \\
(12.283)\end{array}$ & $\begin{array}{c}9.527 \\
(12.509)\end{array}$ \\
\hline $\begin{array}{l}\text { Square of log real GDP } \\
\text { per capita }\end{array}$ & $\begin{array}{l}0.749^{*} \\
(0.437)\end{array}$ & $\begin{array}{c}0.477 \\
(0.479)\end{array}$ & $\begin{array}{c}0.446 \\
(0.477)\end{array}$ & $\begin{array}{c}0.555 \\
(0.397)\end{array}$ & $\begin{array}{c}0.278 \\
(0.466)\end{array}$ & $\begin{array}{c}0.277 \\
(0.480)\end{array}$ \\
\hline Real GDP growth rate & $\begin{array}{l}0.382 * * * \\
(0.109)\end{array}$ & $\begin{array}{c}0.297 * * * \\
(0.109)\end{array}$ & $\begin{array}{c}0.325 * * * \\
(0.105)\end{array}$ & $\begin{array}{c}0.266^{* *} \\
(0.107)\end{array}$ & $\begin{array}{c}0.162 \\
(0.106)\end{array}$ & $\begin{array}{c}0.201 * * \\
(0.100)\end{array}$ \\
\hline $\begin{array}{l}\text { Broad Money to } \\
\text { GDP ratio }\end{array}$ & $\begin{array}{c}-0.036^{* *} \\
(0.015)\end{array}$ & $\begin{array}{c}-0.074 * * * \\
(0.016)\end{array}$ & $\begin{array}{c}-0.062 * * * \\
(0.017)\end{array}$ & $\begin{array}{c}-0.054 * * * \\
(0.015)\end{array}$ & $\begin{array}{c}-0.098^{* * *} \\
(0.017)\end{array}$ & $\begin{array}{c}-0.084 * * * \\
(0.018)\end{array}$ \\
\hline Inflation & $\begin{array}{c}-0.381 * * * \\
(0.116)\end{array}$ & $\begin{array}{l}-0.545^{* * *} \\
(0.125)\end{array}$ & $\begin{array}{c}-0.515^{* * *} \\
(0.131)\end{array}$ & $\begin{array}{c}-0.370^{* * *} \\
(0.117)\end{array}$ & $\begin{array}{c}-0.564 * * * \\
(0.132)\end{array}$ & $\begin{array}{c}-0.558 * * * \\
(0.136)\end{array}$ \\
\hline Deposit interest rate & $\begin{array}{c}0.406^{* * *} \\
(0.114)\end{array}$ & $\begin{array}{c}0.559 * * * \\
(0.133)\end{array}$ & $\begin{array}{c}0.524 * * * \\
(0.138)\end{array}$ & $\begin{array}{c}0.454 * * * \\
(0.128)\end{array}$ & $\begin{array}{c}0.636 * * * \\
(0.156)\end{array}$ & $\begin{array}{c}0.619 * * * \\
(0.158)\end{array}$ \\
\hline $\begin{array}{l}\text { Change of nominal } \\
\text { exchange rate }\end{array}$ & $\begin{array}{c}0.086^{* * *} \\
(0.031)\end{array}$ & $\begin{array}{c}0.098 * * * \\
(0.031)\end{array}$ & $\begin{array}{c}0.103 * * * \\
(0.032)\end{array}$ & $\begin{array}{c}0.052 \\
(0.034)\end{array}$ & $\begin{array}{l}0.060^{*} \\
(0.034)\end{array}$ & $\begin{array}{l}0.067^{*} \\
(0.035)\end{array}$ \\
\hline Exchange rate regime & $\begin{array}{c}-1.742 * * * \\
(0.471)\end{array}$ & $\begin{array}{l}-0.426 \\
(0.524)\end{array}$ & $\begin{array}{l}-0.382 \\
(0.521)\end{array}$ & $\begin{array}{l}-1.995^{* * *} \\
(0.458)\end{array}$ & $\begin{array}{l}-0.772 \\
(0.558)\end{array}$ & $\begin{array}{l}-0.712 \\
(0.572)\end{array}$ \\
\hline $\begin{array}{l}\text { Import and export } \\
\text { to GDP ratio }\end{array}$ & $\begin{array}{l}-0.028^{*} \\
(0.015)\end{array}$ & $\begin{array}{c}0.002 \\
(0.021)\end{array}$ & $\begin{array}{l}-0.007 \\
(0.021)\end{array}$ & $\begin{array}{l}-0.011 \\
(0.018)\end{array}$ & $\begin{array}{c}0.020 \\
(0.024)\end{array}$ & $\begin{array}{c}0.011 \\
(0.024)\end{array}$ \\
\hline Capital account openness & $\begin{array}{c}3.086 * * * \\
(0.582)\end{array}$ & $\begin{array}{c}2.670 * * * \\
(0.677)\end{array}$ & $\begin{array}{c}2.753 * * * \\
(0.688)\end{array}$ & $\begin{array}{c}3.351 * * * \\
(0.546)\end{array}$ & $\begin{array}{c}2.770 * * * \\
(0.627)\end{array}$ & $\begin{array}{c}2.819^{* * *} \\
(0.646)\end{array}$ \\
\hline Observations & 214122 & 195067 & 190509 & 218643 & 199356 & 194716 \\
\hline
\end{tabular}

Notes: leverage 1=total debts/ (total debts + equity) and leverage $2=$ total debts/total assets. Firm and year fixed effects are included and all firm-level controls are lagged one period in all regressions. RZ index is calculated year by year following Rajan and Zingales (1998). Robust standard errors clustered at the industry level are in parentheses. ***, **, and * denote significance level at $1 \%, 5 \%$ and $10 \%$, respectively. 
Table 7. Capital Inflows and Firm-Level Credit Growth: Additional Robustness Checks

\begin{tabular}{|c|c|c|c|c|c|c|}
\hline & \multicolumn{2}{|c|}{$\begin{array}{l}\text { Drop Top and Bottom 5\% } \\
\text { of Dependent Variable }\end{array}$} & \multicolumn{2}{|c|}{$\begin{array}{l}\text { Drop Top and Bottom } 5 \% \\
\text { of Dep. Var., } 1 \% \text { of ZS, CF }\end{array}$} & \multicolumn{2}{|c|}{$\begin{array}{l}\text { Winsorized } \\
\text { Sample }\end{array}$} \\
\hline & $\begin{array}{l}\text { Growth of } \\
\text { Leverage } 1\end{array}$ & $\begin{array}{l}\text { Growth of } \\
\text { Leverage } 2 \\
\end{array}$ & $\begin{array}{l}\text { Growth of } \\
\text { Leverage } 1\end{array}$ & $\begin{array}{l}\text { Growth of } \\
\text { Leverage } 2\end{array}$ & $\begin{array}{l}\text { Growth of } \\
\text { Debt }\end{array}$ & $\begin{array}{l}\text { Growth of } \\
\text { Equity }\end{array}$ \\
\hline $\mathrm{RZ}$ inde $\times \mathrm{FDI}$ & $\begin{array}{c}0.051 \\
(0.032)\end{array}$ & $\begin{array}{c}0.037 \\
(0.028)\end{array}$ & $\begin{array}{c}0.048 \\
(0.030)\end{array}$ & $\begin{array}{c}0.045 \\
(0.032)\end{array}$ & $\begin{array}{c}0.053 \\
(0.085)\end{array}$ & $\begin{array}{c}0.017 \\
(0.036)\end{array}$ \\
\hline $\mathrm{RZ}$ index $\times \mathrm{FPI}$ & $\begin{array}{c}0.027 * * * \\
(0.008)\end{array}$ & $\begin{array}{c}0.031 * * * \\
(0.008)\end{array}$ & $\begin{array}{c}0.030 * * * \\
(0.010)\end{array}$ & $\begin{array}{c}0.038 * * * \\
(0.012)\end{array}$ & $\begin{array}{l}0.071^{* *} \\
(0.035)\end{array}$ & $\begin{array}{c}0.002 \\
(0.018)\end{array}$ \\
\hline $\mathrm{RZ}$ inde $\times \mathrm{FOI}$ & $\begin{array}{l}0.026^{* *} \\
(0.012)\end{array}$ & $\begin{array}{c}0.033 * * * \\
(0.011)\end{array}$ & $\begin{array}{l}0.027 * * \\
(0.011)\end{array}$ & $\begin{array}{c}0.035^{* * *} \\
(0.013)\end{array}$ & $\begin{array}{c}0.080^{* *} \\
(0.036)\end{array}$ & $\begin{array}{l}-0.002 \\
(0.006)\end{array}$ \\
\hline $\begin{array}{l}\text { Property, plant and } \\
\text { equipment to assets ratio }\end{array}$ & $\begin{array}{c}-0.054 * * * \\
(0.017)\end{array}$ & $\begin{array}{c}-0.103 * * * \\
(0.020)\end{array}$ & $\begin{array}{c}-0.041 * * \\
(0.018)\end{array}$ & $\begin{array}{c}-0.098^{* * *} \\
(0.020)\end{array}$ & $\begin{array}{c}-0.245^{* * *} \\
(0.034)\end{array}$ & $\begin{array}{l}-0.036 \\
(0.027)\end{array}$ \\
\hline $\begin{array}{l}\text { (Market capitalization }+ \\
\text { total debt) to assets ratio }\end{array}$ & $\begin{array}{l}-2.479 * * * \\
(0.222)\end{array}$ & $\begin{array}{c}-0.838^{* * *} \\
(0.104)\end{array}$ & $\begin{array}{c}-3.735^{* * *} \\
(0.371)\end{array}$ & $\begin{array}{l}-2.964 * * * \\
(0.710)\end{array}$ & $\begin{array}{c}2.001 * * * \\
(0.269)\end{array}$ & $\begin{array}{c}6.510^{* * *} \\
(0.206)\end{array}$ \\
\hline EBIT to asset ratio & $\begin{array}{l}-1.574 \\
(3.667)\end{array}$ & $\begin{array}{l}-0.999^{*} \\
(0.585)\end{array}$ & $\begin{array}{l}-19.270 * * * \\
(4.183)\end{array}$ & $\begin{array}{l}-4.561 \\
(3.118)\end{array}$ & $\begin{array}{c}-4.203 * * \\
(1.885)\end{array}$ & $\begin{array}{l}10.128 \\
(7.762)\end{array}$ \\
\hline Log sales & $\begin{array}{c}-0.742^{* * *} \\
(0.180)\end{array}$ & $\begin{array}{l}0.486^{*} \\
(0.253)\end{array}$ & $\begin{array}{l}-0.838^{* * *} \\
(0.202)\end{array}$ & $\begin{array}{l}-0.477^{*} \\
(0.282)\end{array}$ & $\begin{array}{c}-10.001 * * * \\
(0.797)\end{array}$ & $\begin{array}{l}-5.431 * * * \\
(0.661)\end{array}$ \\
\hline $\begin{array}{l}\text { Interest expense } \\
\text { to net income ratio }\end{array}$ & $\begin{array}{c}-0.379 * * * \\
(0.064)\end{array}$ & $\begin{array}{c}-0.390 * * * \\
(0.076)\end{array}$ & $\begin{array}{c}-0.341 * * * \\
(0.064)\end{array}$ & $\begin{array}{l}-0.485^{* * *} \\
(0.086)\end{array}$ & $\begin{array}{c}-0.811 * * * \\
(0.137)\end{array}$ & $\begin{array}{c}0.216^{* * *} \\
(0.080)\end{array}$ \\
\hline Z-score & $\begin{array}{c}1.101 * * * \\
(0.180)\end{array}$ & $\begin{array}{c}0.211 * * * \\
(0.062)\end{array}$ & $\begin{array}{c}2.464 * * * \\
(0.366)\end{array}$ & $\begin{array}{c}2.379 * * * \\
(0.505)\end{array}$ & $\begin{array}{c}1.028 * * * \\
(0.128)\end{array}$ & $\begin{array}{c}-0.716^{* * * *} \\
(0.090)\end{array}$ \\
\hline $\begin{array}{l}\text { Cash and short term } \\
\text { investment to assets ratio }\end{array}$ & $\begin{array}{c}-0.073 * * * \\
(0.023)\end{array}$ & $\begin{array}{l}-0.044^{*} \\
(0.022)\end{array}$ & $\begin{array}{c}-0.105^{* * *} \\
(0.021)\end{array}$ & $\begin{array}{l}-0.125 * * * \\
(0.025)\end{array}$ & $\begin{array}{c}0.303 * * * \\
(0.063)\end{array}$ & $\begin{array}{c}-0.207 * * * \\
(0.029)\end{array}$ \\
\hline $\begin{array}{l}\text { Net income }+ \text { depreciation } \\
\text { to assets ratio }\end{array}$ & $\begin{array}{c}0.050 \\
(0.042)\end{array}$ & $\begin{array}{l}-0.001 \\
(0.006)\end{array}$ & $\begin{array}{c}0.188 * * * \\
(0.045)\end{array}$ & $\begin{array}{l}0.084 * * \\
(0.039)\end{array}$ & $\begin{array}{c}0.004 \\
(0.015)\end{array}$ & $\begin{array}{l}-0.063 \\
(0.091)\end{array}$ \\
\hline $\begin{array}{l}\text { Net FDI inflows } \\
\text { to GDP ratio }\end{array}$ & $\begin{array}{c}0.017 \\
(0.088)\end{array}$ & $\begin{array}{l}-0.024 \\
(0.093)\end{array}$ & $\begin{array}{c}0.020 \\
(0.086)\end{array}$ & $\begin{array}{l}-0.100 \\
(0.093)\end{array}$ & $\begin{array}{c}-0.503^{* * *} \\
(0.181)\end{array}$ & $\begin{array}{c}-0.363^{* * *} \\
(0.051)\end{array}$ \\
\hline $\begin{array}{l}\text { Net portfolio inflows } \\
\text { to GDP ratio }\end{array}$ & $\begin{array}{l}-0.047 \\
(0.073)\end{array}$ & $\begin{array}{l}-0.022 \\
(0.069)\end{array}$ & $\begin{array}{l}-0.052 \\
(0.070)\end{array}$ & $\begin{array}{l}-0.060 \\
(0.075)\end{array}$ & $\begin{array}{l}-0.163^{*} \\
(0.097)\end{array}$ & $\begin{array}{l}-0.040 \\
(0.047)\end{array}$ \\
\hline $\begin{array}{l}\text { Net other inflows } \\
\text { to GDP ratio }\end{array}$ & $\begin{array}{c}0.060 \\
(0.064)\end{array}$ & $\begin{array}{c}0.078 \\
(0.058)\end{array}$ & $\begin{array}{c}0.047 \\
(0.063)\end{array}$ & $\begin{array}{c}0.080 \\
(0.067)\end{array}$ & $\begin{array}{l}0.221^{*} \\
(0.118)\end{array}$ & $\begin{array}{l}-0.041 \\
(0.030)\end{array}$ \\
\hline $\mathrm{RZ}$ index & $\begin{array}{c}0.251 \\
(0.181)\end{array}$ & $\begin{array}{c}0.222 \\
(0.151)\end{array}$ & $\begin{array}{c}0.245 \\
(0.155)\end{array}$ & $\begin{array}{c}0.199 \\
(0.137)\end{array}$ & $\begin{array}{l}0.636^{*} \\
(0.379)\end{array}$ & $\begin{array}{l}-0.187 \\
(0.218)\end{array}$ \\
\hline Log real GDP per capita & $\begin{array}{l}27.421 * * * \\
(7.966)\end{array}$ & $\begin{array}{l}11.093 \\
(8.464)\end{array}$ & $\begin{array}{l}32.642 * * * \\
(8.394)\end{array}$ & $\begin{array}{l}30.595 * * * \\
(9.880)\end{array}$ & $\begin{array}{c}-9.601 \\
(16.478)\end{array}$ & $\begin{array}{l}-12.817 \\
(12.462)\end{array}$ \\
\hline $\begin{array}{l}\text { Square of log real GDP } \\
\text { per capita }\end{array}$ & $\begin{array}{l}-0.289 \\
(0.304)\end{array}$ & $\begin{array}{c}0.267 \\
(0.336)\end{array}$ & $\begin{array}{l}-0.443 \\
(0.336)\end{array}$ & $\begin{array}{l}-0.332 \\
(0.425)\end{array}$ & $\begin{array}{l}1.270^{* *} \\
(0.619)\end{array}$ & $\begin{array}{c}0.256 \\
(0.460)\end{array}$ \\
\hline Real GDP growth rate & $\begin{array}{l}-0.111^{*} \\
(0.059)\end{array}$ & $\begin{array}{c}-0.257 * * * \\
(0.059)\end{array}$ & $\begin{array}{l}-0.091 \\
(0.060)\end{array}$ & $\begin{array}{c}-0.221 * * * \\
(0.074)\end{array}$ & $\begin{array}{c}1.018^{* * *} \\
(0.124)\end{array}$ & $\begin{array}{c}0.306^{* * *} \\
(0.102)\end{array}$ \\
\hline $\begin{array}{l}\text { Broad Money to } \\
\text { GDP ratio }\end{array}$ & $\begin{array}{c}-0.076^{* * *} \\
(0.010)\end{array}$ & $\begin{array}{c}-0.090^{* * *} \\
(0.008)\end{array}$ & $\begin{array}{c}-0.082 * * * \\
(0.011)\end{array}$ & $\begin{array}{c}-0.096^{* * *} \\
(0.013)\end{array}$ & $\begin{array}{c}-0.073 * * * \\
(0.021)\end{array}$ & $\begin{array}{c}0.044 * * * \\
(0.014)\end{array}$ \\
\hline Inflation & $\begin{array}{c}-0.375^{* * *} \\
(0.066)\end{array}$ & $\begin{array}{c}-0.440 * * * \\
(0.067)\end{array}$ & $\begin{array}{c}-0.349 * * * \\
(0.065)\end{array}$ & $\begin{array}{c}-0.515^{* * *} \\
(0.081)\end{array}$ & $\begin{array}{c}-0.897 * * * \\
(0.209)\end{array}$ & $\begin{array}{l}-0.005 \\
(0.085)\end{array}$ \\
\hline Deposit interest rate & $\begin{array}{c}0.389 * * * \\
(0.087)\end{array}$ & $\begin{array}{c}0.423 * * * \\
(0.100)\end{array}$ & $\begin{array}{c}0.414 * * * \\
(0.086)\end{array}$ & $\begin{array}{c}0.538 * * * \\
(0.100)\end{array}$ & $\begin{array}{c}1.655^{* * *} \\
(0.213)\end{array}$ & $\begin{array}{c}0.552 * * * \\
(0.067)\end{array}$ \\
\hline $\begin{array}{l}\text { Change of nominal } \\
\text { exchange rate }\end{array}$ & $\begin{array}{c}0.074 * * * \\
(0.018)\end{array}$ & $\begin{array}{c}0.048 * * \\
(0.022)\end{array}$ & $\begin{array}{c}0.076 * * * \\
(0.019)\end{array}$ & $\begin{array}{c}0.092 * * * \\
(0.022)\end{array}$ & $\begin{array}{c}0.257 * * * \\
(0.038)\end{array}$ & $\begin{array}{c}0.106 * * * \\
(0.027)\end{array}$ \\
\hline Exchange rate regime & $\begin{array}{l}-0.416 \\
(0.359)\end{array}$ & $\begin{array}{l}-0.515 \\
(0.409)\end{array}$ & $\begin{array}{l}-0.405 \\
(0.354)\end{array}$ & $\begin{array}{l}-0.883^{*} \\
(0.445)\end{array}$ & $\begin{array}{c}-1.808 * * \\
(0.745)\end{array}$ & $\begin{array}{c}-0.951 * * \\
(0.465)\end{array}$ \\
\hline $\begin{array}{l}\text { Import and export } \\
\text { to GDP ratio }\end{array}$ & $\begin{array}{c}0.023 * * \\
(0.011)\end{array}$ & $\begin{array}{c}0.041 * * * \\
(0.012)\end{array}$ & $\begin{array}{c}0.026^{* *} \\
(0.011)\end{array}$ & $\begin{array}{c}0.053 * * * \\
(0.014)\end{array}$ & $\begin{array}{c}0.036 \\
(0.032)\end{array}$ & $\begin{array}{c}0.051 * * * \\
(0.014)\end{array}$ \\
\hline Capital account openness & $\begin{array}{c}0.994 * * \\
(0.433)\end{array}$ & $\begin{array}{c}0.640 \\
(0.432)\end{array}$ & $\begin{array}{c}0.661 \\
(0.467)\end{array}$ & $\begin{array}{c}0.841 \\
(0.568)\end{array}$ & $\begin{array}{l}4.165 * * * \\
(1.269)\end{array}$ & $\begin{array}{c}0.079 \\
(0.572)\end{array}$ \\
\hline Observations & 170525 & 184743 & 163895 & 159644 & 205667 & 214609 \\
\hline
\end{tabular}

Notes: leverage 1=total debts/ (total debts + equity) and leverage $2=$ total debts/total assets. ZS and CF indicate Z-score and cash flow (measured as sum of net income and depreciation to total asset). Dropping the top and bottom 5 percent observations of Z-score and sum of net income and depreciation to total asset yield similar results. Firm and year fixed effects are included and all firm-level controls are lagged one period in all regressions. Robust standard errors clustered at the industry level are in parentheses. $* * *, *$, and * denote significance level at $1 \%, 5 \%$ and $10 \%$, respectively. 
Table 8. Capital Inflows and Corporate Credit Growth: The Demand Side

\begin{tabular}{|c|c|c|c|c|c|c|}
\hline \multicolumn{7}{|c|}{ Dependent variable: Growth rate of total debt } \\
\hline \multirow[t]{2}{*}{ Indicator } & \multicolumn{3}{|c|}{ Growth rate of net equity value } & \multicolumn{3}{|c|}{$\begin{array}{l}\text { Change in property, plant and } \\
\text { equipment divided by assets }\end{array}$} \\
\hline & $(1)$ & $(2)$ & (3) & $(4)$ & $(5)$ & $(6)$ \\
\hline Indicator $\times$ Net FDI & -0.004 & 0.191 & 0.160 & 0.825 & 1.882 & 1.646 \\
\hline inflows to GDP ratio & $(0.215)$ & $(0.215)$ & $(0.217)$ & $(1.196)$ & $(1.230)$ & $(1.252)$ \\
\hline Indicator $\times$ Net portfolio & -0.128 & -0.046 & -0.054 & 0.337 & 0.552 & 0.489 \\
\hline inflows to GDP ratio & $(0.127)$ & $(0.127)$ & $(0.124)$ & $(0.784)$ & $(0.874)$ & $(0.872)$ \\
\hline Indicator $\times$ Net other & $0.297 * *$ & $0.368 * *$ & $0.340^{*}$ & $1.726^{*}$ & $2.030 *$ & $1.929 *$ \\
\hline inflows to GDP ratio & $(0.146)$ & $(0.162)$ & $(0.174)$ & $(0.962)$ & $(1.092)$ & $(1.090)$ \\
\hline Other controls & yes & yes & yes & yes & yes & yes \\
\hline Observations & 212953 & 193438 & 188998 & 230631 & 210154 & 205477 \\
\hline
\end{tabular}


Table 9. Capital Inflows and Corporate Credit Growth: The Supply Side

\begin{tabular}{|c|c|c|c|c|c|c|}
\hline & \multicolumn{3}{|c|}{ Capital Adequacy Ratio } & \multicolumn{3}{|c|}{$\begin{array}{l}\text { Liquid Assets to Deposits } \\
\text { and Short Term Financing }\end{array}$} \\
\hline & $\begin{array}{l}\text { Overall } \\
(1)\end{array}$ & $\begin{array}{l}\text { High } \\
(2)\end{array}$ & $\begin{array}{c}\text { Low } \\
(3)\end{array}$ & $\begin{array}{l}\text { Overall } \\
(4)\end{array}$ & $\begin{array}{l}\text { High } \\
(5)\end{array}$ & $\begin{array}{c}\text { Low } \\
(6)\end{array}$ \\
\hline Net FDI inflows & 0.075 & -0.185 & $0.301 * * *$ & 0.101 & 0.075 & 0.284 \\
\hline to GDP ratio & $(0.156)$ & $(0.213)$ & $(0.091)$ & $(0.150)$ & $(0.122)$ & $(0.257)$ \\
\hline Net portfolio inflows & 0.148 & 0.170 & $0.222 * *$ & 0.164 & 0.104 & $0.258^{*}$ \\
\hline to GDP ratio & $(0.120)$ & $(0.174)$ & $(0.096)$ & $(0.106)$ & $(0.126)$ & $(0.144)$ \\
\hline Net other inflows & $0.265 * *$ & $0.351 * *$ & $0.258 * *$ & $0.293 * * *$ & $0.192 *$ & $0.480 * * *$ \\
\hline to GDP ratio & $(0.102)$ & $(0.170)$ & $(0.097)$ & $(0.088)$ & $(0.101)$ & $(0.162)$ \\
\hline Other controls & yes & yes & yes & yes & yes & yes \\
\hline \multirow[t]{3}{*}{ Observations } & 397 & 200 & 197 & 428 & 214 & 214 \\
\hline & \multicolumn{3}{|c|}{ Z-score } & \multicolumn{3}{|c|}{ NPL Ratio } \\
\hline & $\begin{array}{l}\text { Overall } \\
\text { (1) }\end{array}$ & $\begin{array}{l}\text { High } \\
(2)\end{array}$ & $\begin{array}{l}\text { Low } \\
\text { (3) }\end{array}$ & $\begin{array}{l}\text { Overall } \\
\text { (4) }\end{array}$ & $\begin{array}{l}\text { High } \\
\text { (5) }\end{array}$ & $\begin{array}{l}\text { Low } \\
(6)\end{array}$ \\
\hline Net FDI inflows & 0.101 & -0.033 & 0.127 & 0.085 & 0.265 & -0.046 \\
\hline to GDP ratio & $(0.149)$ & $(0.207)$ & $(0.181)$ & $(0.161)$ & $(0.274)$ & $(0.171)$ \\
\hline Net portfolio inflows & 0.149 & -0.014 & $0.270 * *$ & 0.158 & $0.583 * *$ & 0.036 \\
\hline to GDP ratio & $(0.112)$ & $(0.176)$ & $(0.122)$ & $(0.121)$ & $(0.235)$ & $(0.126)$ \\
\hline Net other inflows & $0.273 * * *$ & 0.153 & $0.347 * * *$ & $0.281 * *$ & $0.641 * * *$ & $0.231 *$ \\
\hline to GDP ratio & $(0.096)$ & $(0.196)$ & $(0.098)$ & $(0.103)$ & $(0.226)$ & $(0.113)$ \\
\hline Other controls & yes & yes & yes & yes & yes & yes \\
\hline Observations & 406 & 203 & 203 & 395 & 201 & 194 \\
\hline
\end{tabular}

Notes: The analysis is restricted to the sample where data on bank capital and reserves to total assets ratio, or ratio of liquid assets to deposits and short term financing (liquidity), or Z-score, or bank non-performing loans to total loans ratio (NPL ratio) are available. Capital and reserves include funds contributed by owners, retained earnings, general and special reserves, provisions, and valuation adjustments. Capital includes tier 1 capital (paid-up shares and common stock), which is a common feature in all countries' banking systems, and total regulatory capital, which includes several specified types of subordinated debt instruments that need not be repaid if the funds are required to maintain minimum capital levels (these comprise tier 2 and tier 3 capital). Total assets include all nonfinancial and financial assets. Z-score compares the buffer of a country's banking system (capitalization and returns) with the volatility of those returns. It is estimated as (ROA+equity/assets)/sd(ROA) and $\mathrm{sd}(\mathrm{ROA})$ is the standard deviation of ROA. "High" and "Low" indicate higher than or lower than the median value of the corresponding indicator. Country and year fixed effects are included in all regressions. Control variables are the same as those in baseline regressions and are lagged by one period. Robust standard errors are in parentheses. $* * *, * *$, and $*$ indicate significance level at $1 \%, 5 \%$ and $10 \%$, respectively. 